\title{
Recent progress on electrochemical production of hydrogen peroxide
}

\author{
Aniqa Sehrish $^{1} \quad$ Romana Manzoor $^{2} \quad$ Kai Dong $^{1} \quad$ Yuanyuan Jiang $^{1^{*}} \quad$ Yizhong Lu $^{1^{*}}$
}

\begin{abstract}
Hydrogen peroxide $\left(\mathrm{H}_{2} \mathrm{O}_{2}\right)$, first synthesized in 1818 through the acidification of barium peroxide $\left(\mathrm{BaO}_{2}\right)$ with nitric acid, is a clear and colorless liquid which is entirely miscible with water and variety of organic solvents such as carboxylic acid and esters. Anthraquinone process (an old production process of $\mathrm{H}_{2} \mathrm{O}_{2}$ ), a batch process carried out in large facilities is an energy demanding process that requires large facilities, and involves oxidation of anthraquinone molecules and sequential hydrogenation. Moreover, the direct synthesis method enables production in a continuous mode as well as it permits small scale, decentralized production. Many drawbacks associated with these processes such as, energetic inefficiency and inherent disadvantages have motivated researchers, industry and academia to find out alternative for synthesis of $\mathrm{H}_{2} \mathrm{O}_{2}$. Electrochemical route based on catalyst selectively reduce oxygen to hydrogen peroxide. $\mathrm{O}_{2}$ is cathodically reduced to produce $\mathrm{H}_{2} \mathrm{O}_{2}$ via 2-electron pathway or 4-electron pathway to get $\mathrm{H}_{2} \mathrm{O}$. Electrolysis of water has an important place in storage and electrochemical energy conversion process where problem is to choose a sufficiently stable and active electrode for anodic oxygen evolution reaction. Most commonly used catalysts on the cathode are carbon based materials such as carbon black, carbon nanotubes, graphite, carbon sponge, and carbon fiber. In perspective of expanding demand of production and usage of hydrogen peroxide we review the past literature to summarize different production processes of $\mathrm{H}_{2} \mathrm{O}_{2}$. In this review, we mainly focus on electrochemical production of hydrogen peroxide along with other alternatives, such as anthraquinone method for industrial $\mathrm{H}_{2} \mathrm{O}_{2}$ production and direct synthesis process. We also review the catalytic activity, selectivity and stability for enhanced yield of $\mathrm{H}_{2} \mathrm{O}_{2}$. From revision of last two decade's literature including experimental and theoretical data; we argue that successful implementation of electrochemical $\mathrm{H}_{2} \mathrm{O}_{2}$ production can be realized on the basis of stable, active and selective catalyst.
\end{abstract}

Keywords: hydrogen peroxide, direct synthesis, electrochemical synthesis, oxygen reduction reaction, catalytic selectivity and activity

\section{Introduction}

Hydrogen peroxide $\left(\mathrm{H}_{2} \mathrm{O}_{2}\right)$ is a clear and colorless liquid which is entirely miscible with water. Many properties of $\mathrm{H}_{2} \mathrm{O}_{2}$ are still being discovered today, even though it was first synthesized in 1818 through the acidification of barium peroxide $\left(\mathrm{BaO}_{2}\right)$ with nitric acid. ${ }^{[1,2]}$ Afterwards hydrochloric acid was used for the improvement of process to release $\mathrm{H}_{2} \mathrm{O}_{2}$. Thenard established the process of wet chemical oxidation in 1880 s commercial

\footnotetext{
Received: April 17, 2019 Accepted: May 13, 2019 Published: May 23, 2019

* Correspondence to: Yuanyuan Jiang, School of Material Science and Engineering, University of Jinan, Jinan 250022, China; Email: mse_jiangyy@ujn.edu.cn; Yizhong Lu, ujn.edu.cn

${ }^{1}$ School of Material Science and Engineering, University of Jinan, Jinan 250022, China

${ }^{2}$ School of Chemistry and Chemical Engineering, University of Jinan, Jinan 250022, China

Citation: Sehrish A, Manzoor R, Dong K, et al. Recent progress on electrochemical production of hydrogen peroxide. Chem Rep, 2019, 1(2): 81-101.

Copyright: (c) 2019 Yuanyuan Jiang, Yizhong Lu, et al. This is an open access article distributed under the terms of the Creative Commons Attribution License, which permits unrestricted use, distribution, and reproduction in any medium, provided the original author and source are credited.
}

manufacture of aqueous hydrogen peroxide solutions.

$$
\begin{gathered}
\mathrm{BaO}_{2}+2 \mathrm{HCl} \rightarrow \mathrm{BaCl}_{2}+\mathrm{H}_{2} \mathrm{O}_{2} \\
\mathrm{BaCl}_{2}+\mathrm{H}_{2} \mathrm{SO}_{4} \rightarrow \mathrm{BaSO}_{4}+2 \mathrm{HCl} \\
\mathrm{BaO}+\mathrm{H}_{2} \mathrm{SO}_{4} \rightarrow \mathrm{BaSO}_{4}+\mathrm{H}_{2} \mathrm{O}_{2}
\end{gathered}
$$

In 1853 electrochemical processes was introduced to produce hydrogen peroxide by electrolysis of aqueous sulfuric acid $^{[3]}$ which, eliminated the disadvantages of barium peroxide process. In 1878, peroxomonosulfuric acid was electrolyzed to form peroxodisulfuric acid which is further hydrolyzed by water to get sulfuric acid and hydrogen peroxide. Furthermore, Manchot in 1901, found that $\mathrm{H}_{2} \mathrm{O}_{2}$ and quinones (or azobenzenes) can be formed by quantitatively reacting hydroquinones (or hydrazobenzenes) with oxygen. ${ }^{[4]}$ In 1932, a cyclic process based on azobenzenehydrazobenzene was proposed by Walton and Filson in the United States for the manufacture of $\mathrm{H}_{2} \mathrm{O}_{2} \cdot{ }^{[5]}$ Riedl and Pfleiderer in 1939 developed anthraquinone auto-oxidation $(\mathrm{AO})$ process which 
was used to produce $\mathrm{H}_{2} \mathrm{O}_{2}$ on large scale. ${ }^{[6]}$ Industrial production of $\mathrm{H}_{2} \mathrm{O}_{2}$ went through three stages including wet oxidation, electrolysis and organic oxidation process. ${ }^{[7]}$ In 1990s many of serious environmental problems (like formation of dioxins and other harmful chlorinated products) arising from the use of chlorine, raise the concern to replace chlorine with $\mathrm{H}_{2} \mathrm{O}_{2}$ as a bleaching agent in paper production. ${ }^{[8,9]}$ Historical development in industrial production of $\mathrm{H}_{2} \mathrm{O}_{2}$ is summarized in Figure 1. Global capacity of the world (based on 100\% $\left.\mathrm{H}_{2} \mathrm{O}_{2}\right)$ was 1.5 million tonnes per annum $\left(\mathrm{ta}^{-1}\right)$ in $1990 \mathrm{~s}$, which increased to 5.5 million ta ${ }^{-1}$ in $2015,{ }^{[10]}$ while world scale plant built to support synthesis of propene oxide (PO) had a capacity of about $20,000-40,000 \mathrm{ta}^{-1}$ increased to $300,000 \mathrm{ta}^{-1}$. This process opens up several new routes to highly environment beneficial uses of this valuable chemical, turns it into plentiful, affordable and large scale commodity, which was once thought to be an expensive specialty. Furthermore, new research has been carried to find innovative new processes and materials based on $\mathrm{H}_{2} \mathrm{O}_{2}$.

Hydrogen peroxide is soluble in a variety of organic solvents such as carboxylic acid and esters and pure $\mathrm{H}_{2} \mathrm{O}_{2} 100 \%$ wt is stable at room temperature. ${ }^{[7]}$ It is weakly acidic in aqueous solution and forms salts with various metals. It can behave as both reducing and oxidizing agent. General process of working of $\mathrm{H}_{2} \mathrm{O}_{2}$ differs from other types of biocides and anti- infective drugs, by considerably reducing the risk of development of resistance to some kind of biocides over a period of time. In developed and developing countries, the above mentioned property possibly makes it a widespread antimicrobial chemical. $\mathrm{H}_{2} \mathrm{O}_{2}$ is an environment friendly and multipurpose oxidant, which plays a major role in a remarkably diverse range of applications, including pulp and textile bleaching, first-aid kits for disinfection, ${ }^{[12]}$ chemical synthesis, ${ }^{[9,13]}$ wastewater treatment, ${ }^{[14]}$ detergents, exhaust air treatment and semiconductor cleaning (Figure 2a and Figure 2b). An increased trend has been noticed in demand of $\mathrm{H}_{2} \mathrm{O}_{2}$ because of increased efforts to avoid environmental damage. ${ }^{[10]}$ The annual 5.5 million tonnes production of $\mathrm{H}_{2} \mathrm{O}_{2}{ }^{[10]}$ in 2015, significantly exceeds the forecast production made in 2011 which is 4.3 million ta ${ }^{-1} \cdot{ }^{[15]} \mathrm{H}_{2} \mathrm{O}_{2}$ is known as a green oxidant that decomposes in water had a global utilization of 0.5 million $\mathrm{ta}^{-1}$ three decades ago which increased to 4.5 million $\mathrm{ta}^{-1}$ in 2014, and is still increasing. Presently, millions of $\mathrm{ta}^{-1}$ of $\mathrm{H}_{2} \mathrm{O}_{2}$ are being produced, especially for industries to produce chemicals and paper. ${ }^{[16]}$

Expanding demand of production and usage of hydrogen peroxide leads us to review the past literature for gathering information about $\mathrm{H}_{2} \mathrm{O}_{2}$ production. In this review paper we tried to summarize different production processes an eminent green material $\mathrm{H}_{2} \mathrm{O}_{2}$. The main focus of the study is electrochemical production of hydrogen peroxide along with other alternatives such as, anthraquinone method for industrial $\mathrm{H}_{2} \mathrm{O}_{2}$ production and direct synthesis process, keeping the aim of expanding its utilization across different civil and industrial sectors. This study also focuses on the catalytic activity, selectivity and stability for enhanced yield of $\mathrm{H}_{2} \mathrm{O}_{2}$. We review experimental and theoretical data from the past literature and on this basis; we argue that successful implementation of electrochemical $\mathrm{H}_{2} \mathrm{O}_{2}$ production can be realized on the basis of stable, active and selective catalyst.

\section{Production Processes of Hydrogen Perox- ide}

\subsection{Anthraquinone Process}

In recent years more than 3.5 million metric tons of hydrogen peroxide has been produced to meet different usage demands all over the world annually. Nowadays the main production method for exclusive production of $\mathrm{H}_{2} \mathrm{O}_{2}$ is anthraquinone process. ${ }^{[16,18]}$ During World War II (1940s) IG Farbenindustrie in Germany introduced the first commercial anthraquinone autoxidation process plant (360 metric tons $\mathrm{H}_{2} \mathrm{O}_{2}$ annually). ${ }^{[16,19]}$ Following the steps of this plant, some chemical companies started to operate large scale plants, ${ }^{[19]}$ and in these five decades, the original concept of commercial anthraquinone autoxidation process is maintained by all worldwide subsequent anthraquinone-based production plants. ${ }^{[16]}$ However, some of the important improvements were made in each of the four major steps: hydrogenation, oxidation, hydrogen peroxide extraction, and treatment of the working solution.

The largest part anthraquinone process of $\mathrm{H}_{2} \mathrm{O}_{2}$ production involves the main reactions from the RiedlPfleiderer process. ${ }^{[6]}$ In the anthraquinone process, hydrogenation and autoxidation takes place in which dihydrogen is oxidized to $\mathrm{H}_{2} \mathrm{O}_{2}$ with dioxygen from the air by catalytical hydrogenation of 2-alkylanthraquinone (AQ; usually 2-ethylantraquinone) in an appropriate solvent or mixture of solvents. ${ }^{[16,19,20]}$ To make the working solution an appropriate organic solvent is used to dissolve AQ. Furthermore, hydrogenation process is used to produce corresponding anthraquinolor anthrahydroquinone (AHQ) in the presence of catalyst by subjecting AQ in the working solution to reduction with dihydrogen. For reduction of $\mathrm{AQ}$ pure hydrogen gas is blown into the reactor containing Pd catalyst and working solution. ${ }^{[21,22]}$ Afterwards, stirring of working solution takes 


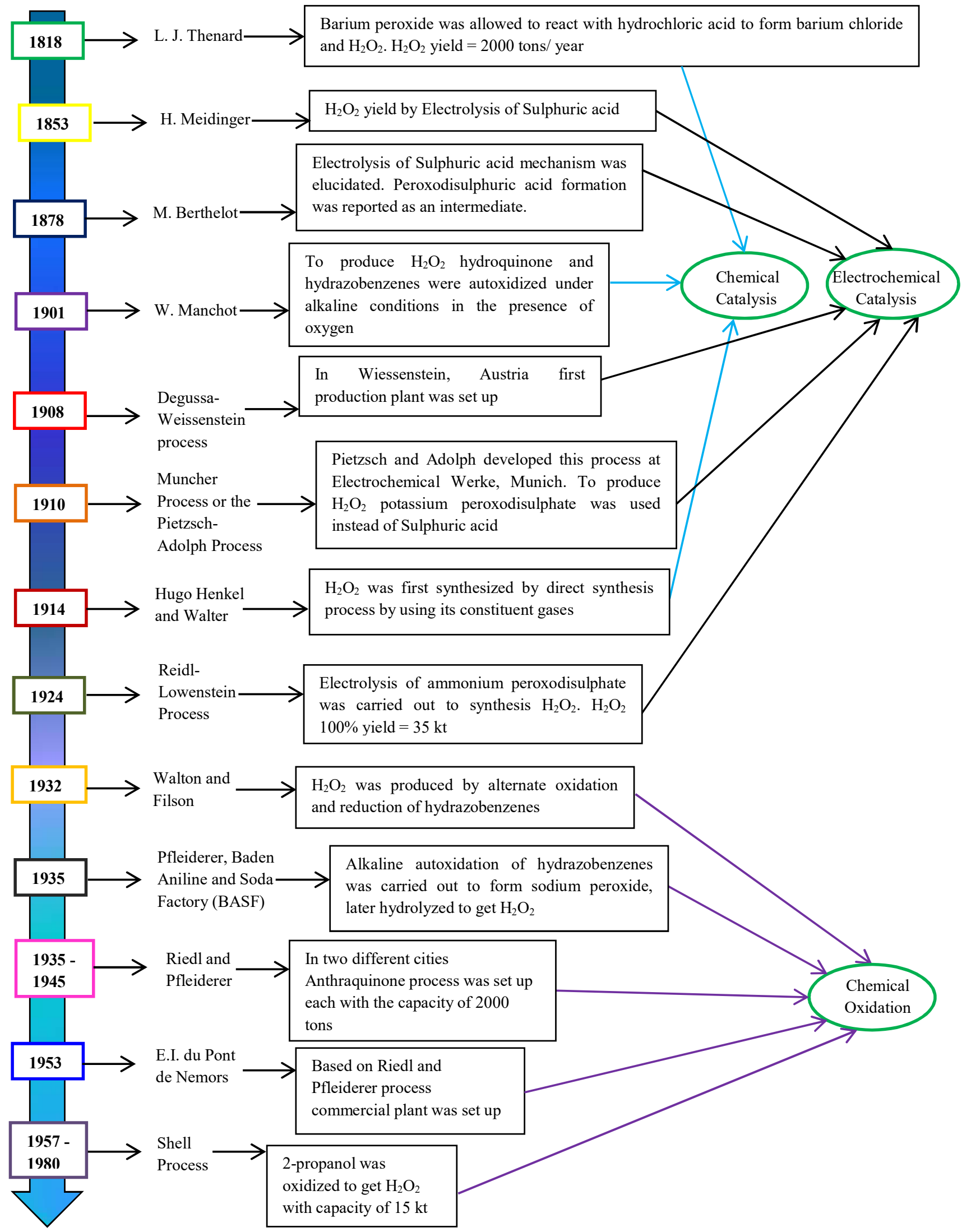

Figure 1. Summary of historical development of industrial production of $\mathrm{H}_{2} \mathrm{O}_{2}{ }^{[11]}$ 

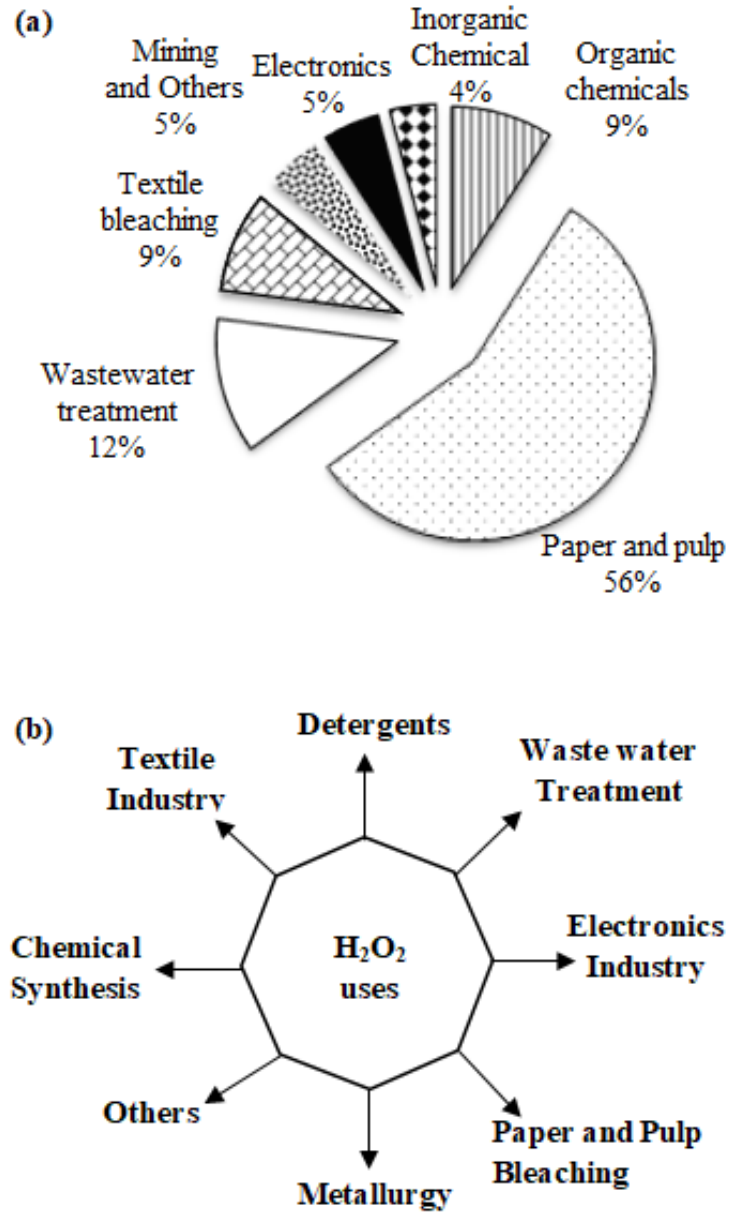

Figure 2. (a) Global market share of $\mathrm{H}_{2} \mathrm{O}_{2}$; (b) Applications of $\mathrm{H}_{2} \mathrm{O}_{2}$

place to activate dihydrogen on palladium surface and to disperse hydrogen gas. In hydrogenation the working solution is hydrogenated using a catalyst at temperature of $40-50^{\circ} \mathrm{C}$ keeping the hydrogen partial pressure to 4 bars. The hydrogenation process is carefully controlled to minimize secondary reactions by keeping conversion of AQ to AHQ under $60 \%$. Pd and nickel catalysts have been used in the hydrogenation step. ${ }^{[23,24]}$ The process of using nickel as a catalyst in the original process for the reduction has two serious drawbacks: rapid deactivation and excessive hydrogenation. In autoxidation process, equimolecular amounts of hydrogen peroxide is produced and AHQ is separated from the hydrogenation catalyst ${ }^{[19]}$ and is re-formed into original AQ again by an oxygen-containing gas or air. This oxidation process typically takes place under slightly compressed conditions with $30-60^{\circ} \mathrm{C}$ in a noncatalytic environment and under mild conditions by bubbling air through the working solution. All these reactions occurs by means of well-documented free radical chain mechanism. ${ }^{[25]}$ Furthermore, demineralized water in a counter column is used to produce aqueous $\mathrm{H}_{2} \mathrm{O}_{2}$ usually $30 \%$ by weight. The aqueous $\mathrm{H}_{2} \mathrm{O}_{2}$ is then distilled to extract pure $\mathrm{H}_{2} \mathrm{O}_{2}$ from the working solution by removing impurities and by increasing the concentration to as high as $70 \%$. The remaining solvent/anthraquinone mixture is recycled in the reduction process to reuse $\mathrm{AQ}$. Therefore, high quantity of $\mathrm{H}_{2} \mathrm{O}_{2}$ can be produced efficiently from the anthraquinone process by using air and hydrogen gas.

During hydrogenation process some amount of AQ is converted into THAQ and compared to AQ Tetrahydroanthraquinone (THAQ) can easily be hydrogenated to tetrahydroanthrahydroquinone (THAHQ) when takes part in the anthraquinone process. ${ }^{[26]}$ Both THAQ and AQ co-exist in the working solution ${ }^{[20]}$ though, THAHQ oxidizes slowly to produce $\mathrm{H}_{2} \mathrm{O}_{2}$ as compared to $A H Q .{ }^{[27]}$ Although, the anthraquinone process got industrial importance and some kinetic aspects have been reported but reaction mehanisim involved in the autoxidation process of AHQ and THAHQ is still unknown. Anthraquinone process ( Figure 3), which is a batch process carried out in large facilities, is an old production process of $\mathrm{H}_{2} \mathrm{O}_{2}$ with an average yield of $50 \mathrm{ta}^{-1}$ per plant. Many drawbacks are associated with this plant such as it is an energy demanding process, requires large facilities, ${ }^{[16]}$ and involves oxidation of anthraquinone molecules and sequential hydrogenation. The energetic inefficiency and inherent disadvantages of anthraquinone process have motivated researchers, industry and academia to find out alternative and driven their interest towards direct synthesis of $\mathrm{H}_{2} \mathrm{O}_{2}{ }^{[28,29]}$ which is a small-scale and catalytic process for continuous production. ${ }^{[16]}$ Pd-modified Au nanoparticles (henceforth denoted as $\mathrm{Pd} / \mathrm{Au}$ ) are the most active catalysts for this process. Palladium based catalysts are more selective second generation catalysts but cannot completely avoid hydrogenation by-products (extra consumption of anthraquinone and hydrogen). Therefore, a highly selective catalyst is required to hydrogenate the carbonyl group leaving the aromatic group intact. A new generation of catalysts are required to fulfill these requirements such as, catalysts based on chemically reduced nanosized amorphous $\mathrm{Ni} / \mathrm{Cr} / \mathrm{B}^{[30]}$ and $\mathrm{Ni} / \mathrm{B}^{[31,32]}$ alloys. $0.1 \% \mathrm{w} / \mathrm{w}$ of di-n-octylamine (slightly watersoluble secondary amine) can be added in the working solution to accelerate the oxidation reaction.

The yield of $\mathrm{H}_{2} \mathrm{O}_{2}$ extracted by water is $95 \%$ of the theoretical amount of hydrogen peroxide. Water is most commonly used to separate $\mathrm{H}_{2} \mathrm{O}_{2}$ from working solution while many other methods are also present. The concentration of $\mathrm{H}_{2} \mathrm{O}_{2}$ in the working solution is between 

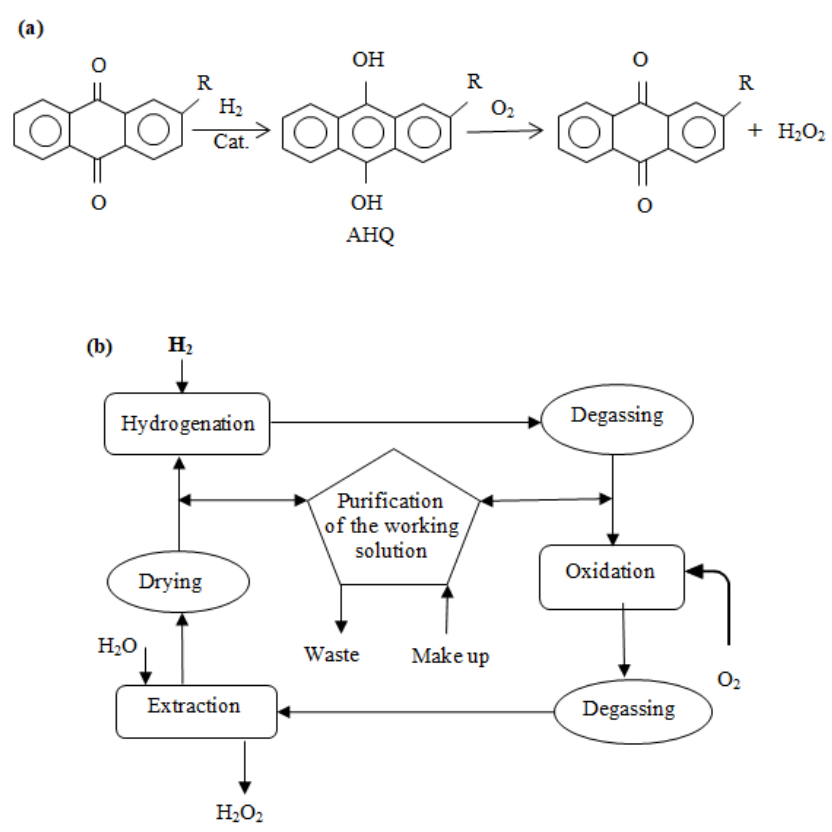

Figure 3. (a) The overall reaction of hydrogen peroxide preparation with the anthraquinone process; ${ }^{[18]}$ (b) Diagram of anthraquinone process for Synthesizing $\mathrm{H}_{2} \mathrm{O}_{2}{ }^{[16]}$

0.8 and $1.9 \% \mathrm{w} / \mathrm{w}$ which can be recovered up to $95 \%$ by efficient extractors. The study presents only simplified process including different reactions involved in the process however, a series of other reactions can also occur in this process and leads to a net consumption of anthraquinone. Along with the main advantage of AO process in high yield of $\mathrm{H}_{2} \mathrm{O}_{2}$ per cycle, there are also major disadvantages related to the process. The main disadvantage is from steps of separation involved in purifying $\mathrm{H}_{2} \mathrm{O}_{2}$ from the organic impurities and side reactions occurring in the process which requires hydrogenation of the catalyst and regeneration of the solution. Literature proposed improvements in this process at each step, despite that the process provides the highest yield of $\mathrm{H}_{2} \mathrm{O}_{2}$ per cycle.

\subsection{Direct Synthesis of $\mathbf{H}_{2} \mathbf{O}_{2}$}

The direct synthesis of hydrogen peroxide from hydrogen and oxygen is atom efficient and an attractive route to the current commercial production process for this important chemical commodity. Currently indirect anthraquinone process is used to produce many million metric tonnes of $\mathrm{H}_{2} \mathrm{O}_{2}$ out of which $80 \%$ is used for textile bleaching, chemical synthesis and paper industries. ${ }^{[16]}$ This demand of $\mathrm{H}_{2} \mathrm{O}_{2}$ is going to increase as the demand for propylene oxide is exceeding. Concentrated $\mathrm{H}_{2} \mathrm{O}_{2}$ is produced by the indirect process and has to be transported to the point of use for dilution up to $28 \mathrm{wt} \%$ whereas; in direct route $\mathrm{H}_{2} \mathrm{O}_{2}$ is produced at its point of use. Hence the development of a catalytic process is required for this reason. This process gained considerable research interest of the community into catalysts that can provide an alternative to the current industrial process. Most of the evaluated catalyst systems utilize Pd as the active catalyst. There are a number of ways to promote activity of the catalyst such as, adding second metal or addition of reactant phase like halides or acid. ${ }^{[33]}$

The "direct catalytic" synthesis process of $\mathrm{H}_{2} \mathrm{O}_{2}$ is a promising alternative to previous batch synthesis methods and has long been a dream process, which involves the direct reaction of $\mathrm{H}_{2}$ and $\mathrm{O}_{2}$ in a liquid solvent using $\mathrm{Au} / \mathrm{Pd}$ as a catalyst. ${ }^{[28,34]}$ It was first reported in $1914 .{ }^{[35]}$ The direct synthesis method enables production in a continuous mode as well as it permits small scale, decentralized production. Industrial viability of the process depends on the cathodic catalysis of oxygen reduction. It is a straightforward batch process, in which $\mathrm{H}_{2} \mathrm{O}_{2}$ is produced by simultaneously introducing both $\mathrm{H}_{2}$ and $\mathrm{O}_{2}$ into a liquid medium in the presence of catalyst (Figure 4a). It requires transport $\mathrm{H}_{2}$, while avoid the need to transport $\mathrm{H}_{2} \mathrm{O}_{2}$ to site. The process involves the mixture of $\mathrm{H}_{2}$ and $\mathrm{O}_{2}$, so these gases are diluted into $\mathrm{N}_{2}$ or $\mathrm{CO}_{2}$ to avoid entering into flammable range. ${ }^{[36]}$ Production of $\mathrm{H}_{2} \mathrm{O}_{2}$ consists of the selective hydrogenation of $\mathrm{O}_{2}$ (Figure $4 \mathrm{~b}$ ). The catalyst should prevent $\mathrm{H}_{2} \mathrm{O}_{2}$ decomposition and should provide conditions to sustain high rates of $\mathrm{H}_{2} \mathrm{O}_{2}$ while minimize the further reduction of $\mathrm{H}_{2} \mathrm{O}_{2}$ to $\mathrm{H}_{2} \mathrm{O}$. Most experiments have focused on Pd or Pd-based catalysts;. ${ }^{[28,33,37,38]}$ Specially, Hutchings and co-workers have produced inspiring works in this area on PdSn and PdAu catalysts. ${ }^{[28,33,36,39-43]}$ The suggested method for direct synthesis of $\mathrm{H}_{2} \mathrm{O}_{2}$ involves following steps: at the start of the reaction $\mathrm{H}_{2}$ molecules dissociate into hydrogen atom on the catalyst surface. Following the reaction $\mathrm{OOH}$ intermediate is formed when an $\mathrm{O}_{2}$ molecule adsorbs on the surface of catalyst and reacts with hydrogen atom. ${ }^{[29,44]}$ Subsequently, $\mathrm{H}_{2} \mathrm{O}_{2}$ if formed when $\mathrm{OOH}$ intermediate reacts with another hydrogen atom, later on desorption of $\mathrm{H}_{2} \mathrm{O}_{2}$ from the catalyst surface occurs. ${ }^{[15,37,41,44]}$

Unfortunately, the problems associated with the direct synthesis of $\mathrm{H}_{2} \mathrm{O}_{2}$ are very often minimized and are overlooked in literature. Whereas, the direct synthesis of $\mathrm{H}_{2} \mathrm{O}_{2}$ using $\mathrm{H}_{2}$ and $\mathrm{O}_{2}$, would be a highly desirable process that avoids the production of any waste (except harmless water) ${ }^{[45]}$ It was noted in 1999 that there is no such industrial plant that is commissioned and designed using the alternative technologies to the AO process. Based on this observation "Clark and Jones" mentioned in their studies that although the anthraquinone process 
(a)

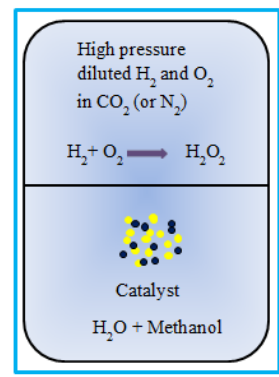

(b)

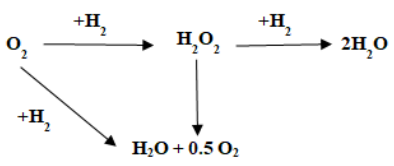

Figure 4. (a) Schematic diagram of direct synthesis of $\mathrm{H}_{2} \mathrm{O}_{2}$; (b) Reaction pathway of direct synthesis of $\mathrm{H}_{2} \mathrm{O}_{2}$

require deactivated hydrogenation catalyst and replacement of the quinone over a period of time, but "the process will continue to dominate". [46] Development of an alternative and industrially viable process based on direct synthesis with noble metal catalysis has gained interest of industrial research in past few decades. ${ }^{[15]}$ From 1980 to 1999 more than 100 patents were granted to large chemical companies.

In Germany (2006), a one tonne demonstration plant was built by a joint project between a catalyst supplier (Headwaters Technology Innovation) and a large $\mathrm{H}_{2} \mathrm{O}_{2}$ manufacturer (Degussa, now Evonik) for the aim to begin commercial production in 2009 by collecting and evaluating necessary data for designing 200,000 $\mathrm{ta}^{-1}$ plant the aim was to collect and evaluate data necessary to design a 200,000 ta ${ }^{-1}$ plant. ${ }^{[4]}$ A carbon-supported $\mathrm{PdPt} / \mathrm{C}$ catalyst comprised of uniform $4 \mathrm{~nm}$ metal alloy nanoparticles was used in the process. Even though, the process was announced to be commercially available starting from 2009, but direct synthesis can only be achievable with pure and costly $\mathrm{O}_{2}$ instead of freely available air, so it was not commercialized (advantages and disadvantages summarized in Figure 5). Besides this reason generally a higher reaction pressure is required compared to AO process. Such as alloyed $\mathrm{Pd} / \mathrm{Sn}$ nanoparticles comprised catalyst supported on $\mathrm{TiO}_{2}$, and capable of affording $\mathrm{H}_{2} \mathrm{O}_{2}$ with $>95 \%$ selectivity, works well when pressurized at 29 bars with 5:1 ratio of $\mathrm{O}_{2}$ and $\mathrm{H}_{2}$ dissolved in $\mathrm{MeOH} .{ }^{[38]}$ Direct reaction of oxygen and hydrogen on modified $\mathrm{Pd}$ catalysts can provide significant yields and selectivities to $\mathrm{H}_{2} \mathrm{O}_{2}$. The pre-reduction of the catalyst and usage of mixed solvents especially containing alcohol leads to higher activities and selectivities. ${ }^{[4]}$ Environmental impact of industrial oxidation can be decreased by successful implementation of the direct synthesis of inexpensive $\mathrm{H}_{2} \mathrm{O}_{2}$ that can enable a number of ground-breaking processes (e.g., selective oxidations of alkanes to alcohols). ${ }^{[49]}$

\subsection{Electrochemical synthesis of $\mathrm{H}_{2} \mathrm{O}_{2}$}

Continued increase in global population and economic development is placing an increased pressure on energy resources. A significant amount of chemicals are generated in centralized locations ${ }^{[55]}$ from consumption of raw material and a large fraction of the world's total energy. However, energy and cost can be saved with confined production of chemical, closer to the point of consumption. Electrochemical devices can be helpful in playing a major role in the transformation, as they require minimal capital investment and can be operated at ambient pressures and temperature in small plants. ${ }^{[56]}$ Herein, production of hydrogen peroxide from reduction of oxygen is focused, a chemical with particularly increased electrochemical production. ${ }^{[16]}$ Direct process of $\mathrm{H}_{2} \mathrm{O}_{2}$ synthesis does not make use of embedded energy released upon reacting $\mathrm{H}_{2}$ and potentially explosive mixtures of oxygen and hydrogen are need to be handled during the process. Noting these drawbacks, an electrochemical route based on catalyst are proposed by a growing community of researchers, that selectively reduce oxygen to hydrogen peroxide. ${ }^{[57-59]}$ In this way oxygen are hydrogen are kept separated hence reducing the risk of explosion. Furthermore, the energy released during the reaction can be recovered by production of $\mathrm{H}_{2} \mathrm{O}_{2}$ in a fuel cell. The use of $\mathrm{H}_{2}$ can be avoided when produced in electrolyzer using water as the proton source.

Electrolysis of water has an important place in storage and electrochemical energy conversion process. ${ }^{[60]}$ Along with the advantages of water electrolysis the most complex problem is to choose a sufficiently stable and active electrode for anodic oxygen evolution reaction OER. ${ }^{[61-63]}$ In water electrolysis of proton-exchange membrane most of the materials are not capable of sustaining the acidic medium at high anodic potential, so the choice of material selection is largely reduced to iridium (Ir) based anodes. ${ }^{[64]}$ In last decades many oxides studied based on their OER activity and water electrolysis in solid and liquid alkaline electrolysis cells have gained interest of scientific community. ${ }^{[60,62,63]}$ Most of transition metal oxides when noticing their utilization in combination with conductive binders (most widely employed is carbon material) are found to be poor electron conductors[. ${ }^{[62,65-67]}$ Carbon corrosion simultaneously occurs with the OER at high anodic potential as it is unavoidable. Therefore, a strong determination of the OER current efficiency requires accurate measurements of the OER activities of oxides studied in the presence of carbon additives. ${ }^{[62]}$ The amount of the evolved oxygen can be quantified by the various suggested techniques including scanning electrochemical mass spectrometry, ${ }^{[68,69]}$ online and differential mass spectrometry, ${ }^{[70-74]}$ fluores- 

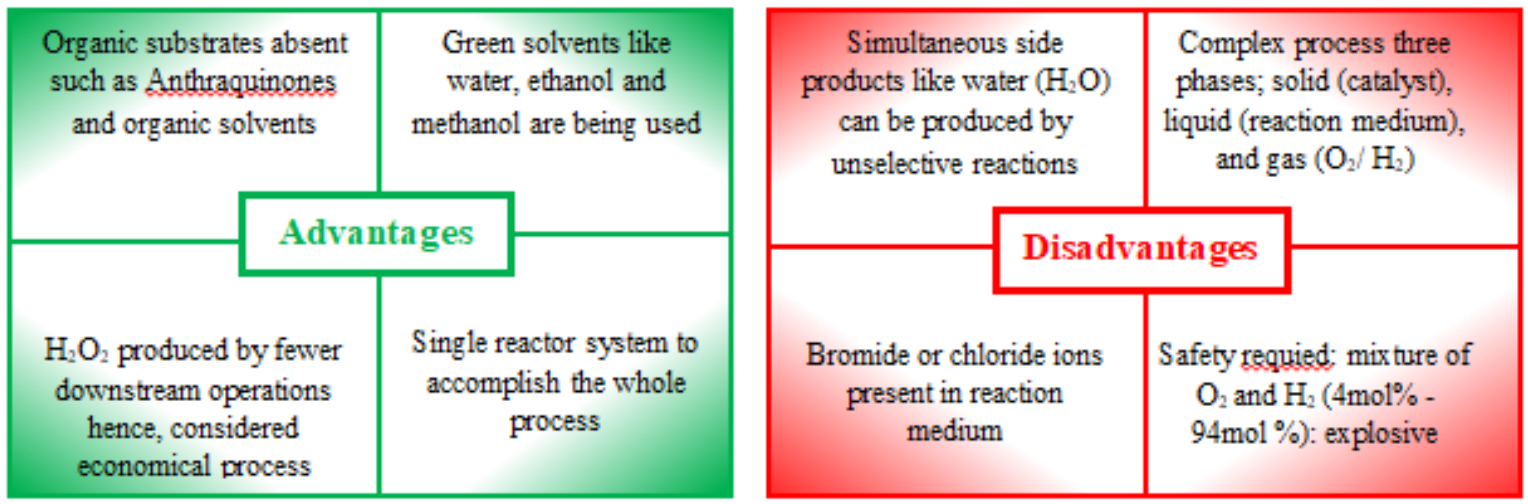

Figure 5. Advantages and disadvantages of direct synthesis route ${ }^{[50-54]}$

cence oxygen sensors. ${ }^{[75,76]}$

The rotating ring-disc electrode (RRDE) is considered by a low detection limit in which the ring detects oxygen evolved at a disk electrode and does not require special cell development. Therefore, RRDE seems to be a convenient method for determining the OER efficiency of carbon/oxides composite electrodes while, the method is hardly applied to studies of the OER. Even the OER current efficiencies for carbon-free electrodes are reported from $100 \%{ }^{[77,78]}$ to much lower values $\left.{ }^{[79-81]}\right]$ thus, suggesting possible instrumental complications. One of the problems with low OER efficiencies can be the result of high catalyst loadings on the disc electrode, while the oxygen evolution condition can also block the pore of the catalytic layers by oxygen bubbles. Catalyst loading still effect seems to be a matter of controversy: some publications documented an independence ${ }^{[82-84]}$ while others a decrease, ${ }^{[78,82,85]}$ or even an increase of the OER specific activity with the loading. ${ }^{[85]}$

The rotating ring-disk electrode (RRDE) is powerful but simple electrochemical method which uses three electrode cells in liquid electrolytes and the production of $\mathrm{H}_{2} \mathrm{O}_{2}$ is quantitatively measured from oxygen reduction process (Figure 6). When compared to catalytic tests in real electrochemical devices, RRDE tests seems to provide yield high reproducibility on a laboratory scale and are simpler to optimize. ${ }^{[86,87]}$ Reduction of oxygen takes place at the disk electrode. The catalyst applied to the disk electrode can be either a planar extended surface, a bulk or a thin film of supported nanoparticles. ${ }^{[87]}$ Rotating motion of the electrode causes forced convection that radially transfers $\mathrm{H}_{2} \mathrm{O}_{2}$ produced at the disk electrode to the concentric platinum ring electrode. Later, at ring electrode $\mathrm{H}_{2} \mathrm{O}_{2}$ is oxidized back to $\mathrm{O}_{2}$.

The selectivity of the ring current and the disk current can be measured by two means, (i) in terms of the frac-

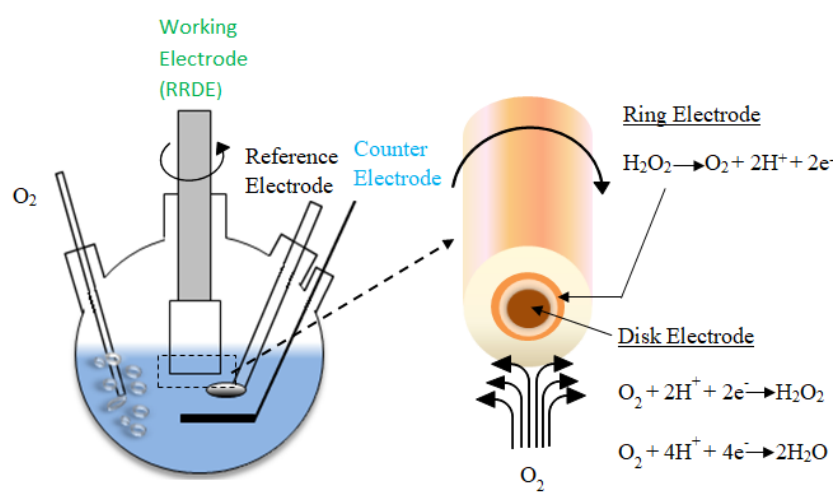

Figure 6. Schematic diagram of $\operatorname{RRDE}^{[50-54]}$

tion of $\mathrm{O}_{2}$ used for $\mathrm{H}_{2} \mathrm{O}_{2} \cdot{ }^{[87]}$

$$
\mathrm{O}_{2} \text { efficiency }(\%) \lambda_{O_{2}}=\frac{2 \times \frac{i R}{N}}{I_{D}+I_{R} / N} \times 100
$$

(ii) the Faradaic efficiency

$$
\text { Faradiac efficiency }(\%) \lambda_{\text {Faradiac }}=\frac{\frac{i R}{N}}{i_{D}} \times 100
$$

where $\mathrm{iD}$ and $\mathrm{iR}$ are disk and ring current, respectively, and $\mathrm{N}$ is the collection efficiency of RRDE, or $\mathrm{H}_{2} \mathrm{O}_{2}$ selectivity on the rotating ring-disk electrode can also be calculated based on the current of both disc and ring electrodes (Equation 6).

$$
\mathrm{H}_{2} \mathrm{O}_{2} \text { Yeild: } \mathrm{H}_{2} \mathrm{O}_{2}(\%)=200^{*} \frac{\frac{i_{R}}{N}}{I_{D}+I_{R} / N}
$$

\subsection{Electroreduction of Oxygen}

Presently, centralized reactors are being used for large scale production of the most common chemicals, such as hydrogen peroxide, hydrogen, ammonia, and methanol. The process is so common, ${ }^{[88,89]}$ that both the chemi- 
cal synthesis and energy conversion takes place closer to the point of consumption for a more decentralized infrastructure. For reaching this goal an increasingly important role is played by the electrochemical devices; they require little auxiliary plants and can be operated at variable rates under ambient conditions. ${ }^{[90]}$ Such devices can be coupled with alternating renewable power sources, like wind or solar power, and provides means to level out demand and store electricity. Herein, we focus on the electroreduction of oxygen to produce hydrogen peroxide. To locally produce a valuable chemical product from an abundant resource, a very attractive route could be provided by electrochemical production of $\mathrm{H}_{2} \mathrm{O}_{2}$ from water oxidation. Production of $\mathrm{H}_{2} \mathrm{O}_{2}$ from $\mathrm{O}_{2}$ and $\mathrm{H}_{2}$ is an exergonic process, which forms Gibbs free energy $\Delta \mathrm{G}_{f}{ }^{0}=120 \mathrm{kj} \cdot \mathrm{mol}^{-1} \cdot \mathrm{H}_{2} \mathrm{O}_{2}$ produced in an electrolyzer or fuel cell by electroreduction of oxygen has significant advantages over the anthraquinone processes. Unlike direct synthesis route, the process is effective in on-site production of hydrogen peroxide whereas, there is no need for $\mathrm{H}_{2}$ and $\mathrm{O}_{2}$ to be maintained outside the explosive regime. Furthermore, in principle, it is possible to recovers most of the $\Delta \mathrm{G}_{f}{ }^{o}=120 \mathrm{kj} \cdot \mathrm{mol}^{-1}$, as electrical energy when produced in a fuel cell. Instead, $\mathrm{H}_{2} \mathrm{O}_{2}$ can be synthesized at the cathode of the electrolyser by doing away with $\mathrm{H} 2$ altogether; the energy input would be $\sim 200$ kj. mol ${ }^{-1}$ with oxygen evolution occurring at its anode. However, for an electroreduction of oxygen, an active, selective and stable catalyst is required in industrially viable electrochemical production of $\mathrm{H}_{2} \mathrm{O}_{2}{ }^{[16,58,59,91,92]}$ Porphyrins based 3d transition metal such as, Co are found to be most selective and active catalyst for this reaction. Though, a rapid loss of performance occurs when in the presence of $\mathrm{H}_{2} \mathrm{O}_{2}$, nitrogen ligands of these catalysts starts degrading. ${ }^{[93,94]}$ Alternatively, noble metal based catalysts are stable even under harsh reaction conditions.

$\mathrm{H}_{2} \mathrm{O}_{2}$ production through $\mathrm{Au}$ nanoparticles shows a diffident selectivity of only $80 \%$ and activity of $1 \mathrm{~mA}$ at $0.4 \mathrm{~V}$ overpotential. Instead, similar activity and up to $90 \%$ selectivity is showed by $\mathrm{Pd} / \mathrm{Au}$ nanoparticles to $\mathrm{Au}{ }^{[58]}$ Siahrostami, Verdaguer-Casadevall ${ }^{[95]}$ carried out a study on electrochemical generation of $\mathrm{H}_{2} \mathrm{O}_{2}$ to discover new alloys for exhibiting an unprecedented combination of stability, activity and selectivity. $\mathrm{H}_{2} \mathrm{O}_{2}$ decomposes in alkaline conditions or at high temperature ${ }^{[16]}$ so, the study specifically focus on ambient conditions functioning catalysts, that contains elements stable in acidic, rather than basic electrolytes. At such conditions low membrane stability, low hydrogen oxidation activity and poor water management can occur by hydroxide-conducting polymeric electrolytes based de- vices. ${ }^{[96,97]}$ Two coupled proton and electron transfer process is involved in electroreduction of $\mathrm{O}_{2}$ to $\mathrm{H}_{2} \mathrm{O}_{2}:{ }^{[98]}$

$$
\begin{gathered}
\mathrm{O}_{2}+*+\left(\mathrm{H}^{+}+e^{-}\right) \rightarrow \mathrm{HOO} * \\
\mathrm{HOO} *+\left(\mathrm{H}^{+}+e^{-}\right) \rightarrow \mathrm{H}_{2} \mathrm{O}_{2}+*
\end{gathered}
$$

where $\mathrm{HOO}^{*}$ denotes the single adsorbed intermediate for the reaction and $*$ denotes an unoccupied active site. High selectivity and activity is provided by the catalyst by maximizing and minimizing the kinetic barriers for $\mathrm{HOO}^{*}$ and barriers for Equation 7 and Equation 8 respectively. $\mathrm{HOO}^{*}$ dissociates or reduces to intermediates $\left(\mathrm{O}^{*}\right.$ and $\left.\mathrm{H}^{*}\right)$ of the four electron reduction of $\mathrm{O}_{2}$ to $\mathrm{H}_{2} \mathrm{O}$. An interplay between electronic and ensemble effects are used to determine the selectivity and activity of the catalyst. Electronic effect controls the binding of the reaction intermediates ${ }^{[99,100]}$ and the binding of $\mathrm{HOO}^{*}$ to the surface is dependent on the catalyst material. Therefore, for controlling the catalyst activity, $\mathrm{HOO}^{*}$ binding energy, is found to be the descriptor, or key parameter. A constant amount of $3.2 \pm 0.2 \mathrm{eV}$ is used by $\mathrm{HOO}^{*}$ for bonding linearly with that of $\mathrm{HO}^{*}{ }^{[101]}$

$$
\mathrm{HO} *+\left(\mathrm{H}^{+}+e^{-}\right) \rightarrow \mathrm{H}_{2} \mathrm{O}+*
$$

To drive $\mathrm{H}_{2} \mathrm{O}$ formation on with an optimistical catalyst a minimum $\eta \mathrm{O}_{2} / \mathrm{H}_{2} \mathrm{O} \sim 0.4 \mathrm{~V}$ is required as compared to two electron transfer. The binding energies of intermediates like $\mathrm{HO}^{*}$ and $\mathrm{HOO}^{*}$ scales linearly with others ${ }^{[102]}$ to overcome this problem reactions that involves more than two electrons require high value of $\eta \mathrm{O}_{2} / \mathrm{H}_{2} \mathrm{O} \cdot{ }^{[98,99,101,102]}$ Reduction of $\mathrm{O}_{2}$ to $\mathrm{H}_{2} \mathrm{O}_{2}$ is a characteristic of two-electron transfer reaction which requires the negligible overpotential, where ideal catalyst finding has an insignificant criterion. Tendency to break $\mathrm{OO}$ bond determines the selectivity of the catalyst towards $\mathrm{H}_{2} \mathrm{O}$ or $\mathrm{H}_{2} \mathrm{O}_{2}$. Consecutively, the tendency is set by the binding strengths of the intermediates of the fourelectron pathway, $\mathrm{O}^{*}$ and $\mathrm{HO}^{*}$. The strong $\mathrm{HO}^{*}$ binding of the four-electron makes it dominate in selectivity over the two-electron pathway, hence there is less free energy to form $\mathrm{H}_{2} \mathrm{O}$ from $\mathrm{HO}^{*}$.

Electrochemical synthesis of $\mathrm{H}_{2} \mathrm{O}_{2}$ solves the issues related to the indirect anthraquinone process ${ }^{[59,95,103-107]}$ and is a straightforward on-site production process. Electrochemical generation of $\mathrm{H}_{2} \mathrm{O}_{2}$ via two-electron oxidation of water is one of the striking possible route (Equation 10): ${ }^{[108,109]}$

$$
2 \mathrm{H}_{2} \mathrm{O} \rightarrow \mathrm{H}_{2} \mathrm{O}_{2}+2\left(\mathrm{H}^{+}+e^{-}\right) \quad E^{o}=1.76 \mathrm{~V}
$$

Two valuable products $\left(\mathrm{H}_{2} \mathrm{O}_{2}\right.$ and $\left.\mathrm{H}_{2}\right)$ (Equation 9) are achieved by coupling (Equation 10) and the hydrogen 


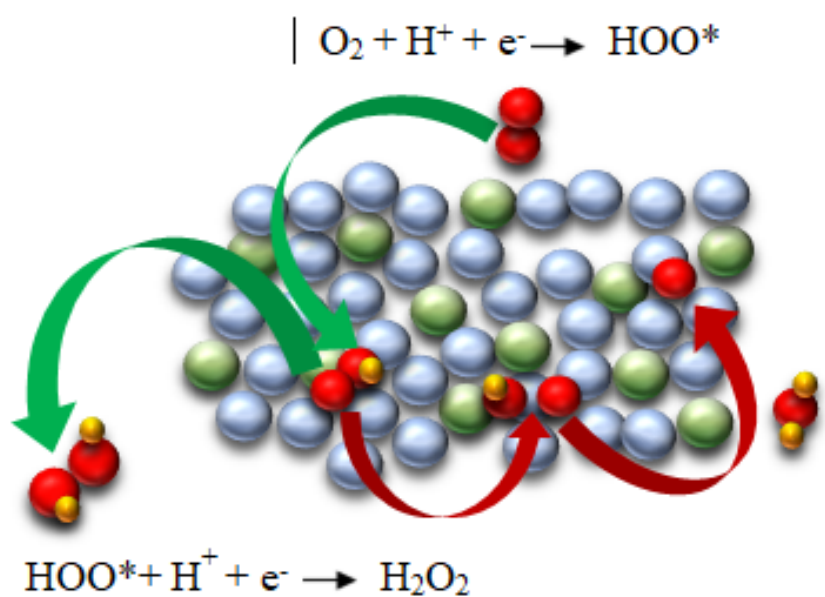

Figure 7. Theoretical modelling of oxygen reduction to $\mathrm{H}_{2} \mathrm{O}$ and $\mathrm{H}_{2} \mathrm{O}_{2}$, Representation of the $\mathrm{PtHg}_{4}$ (110) surface, based on the investigation of $\mathrm{Hg} / \mathrm{Pt}(111)^{[95]}$ and $\mathrm{Pd}_{2} \mathrm{Hg}_{5}(001) .^{[103]}$ The green arrows represent the reaction path to $\mathrm{H}_{2} \mathrm{O}_{2}$, whereas the red arrows the path to $\mathrm{H}_{2} \mathrm{O}$. Mercury, grey; platinum / palladium, green; oxygen, red; hydrogen, yellow.

evolution reaction (Equation 11) using only water as raw material in a single electrochemical device. Sunlight can be used for both reactions by using photo-absorber with such devices: ${ }^{[110,111]}$

$$
\begin{gathered}
2\left(\mathrm{H}^{+}+e^{-}\right) \rightarrow \mathrm{H}_{2} \quad E^{o}=0.0 \mathrm{~V} \\
2 \mathrm{H}_{2} \mathrm{O} \rightarrow \mathrm{H}_{2} \mathrm{O}_{2}+\mathrm{H}_{2}
\end{gathered}
$$

Though, the two-electron water oxidation (Equation 10) couples with four-electron oxidation reaction to generate $\mathrm{O}_{2}$ (Equation 13) and with the one-electron oxidation reaction to produce $\mathrm{OH}$ radical (Equation 14).

$$
\begin{gathered}
2 \mathrm{H}_{2} \mathrm{O} \rightarrow \mathrm{O}_{2}+4\left(\mathrm{H}^{+}+e^{-}\right) E^{o}=1.23 \mathrm{~V} \\
\mathrm{H}_{2} \mathrm{O} \rightarrow \mathrm{OH}^{*}(a q)+\left(H^{+}+e^{-}\right) E^{o}=1.23 \mathrm{~V}
\end{gathered}
$$

The relevant intermediates for the water oxidation reactions of one- (Equation 14), two- (Equation 10) and four-electron (Equation 13) are $\mathrm{OH}^{*}, \mathrm{O}^{*}$, and $\mathrm{OOH}^{*}$ respectively. The main focus of the water oxidation research is the $\mathrm{O}_{2}$ generation reaction (Equation 13), ${ }^{[83,112-114,125]}$ on the other hand oxidation reaction of water to $\mathrm{H}_{2} \mathrm{O}_{2}$ (Equation 10) by selective two electron method is considered as much more difficult process and has gained less attention. Presently, the main challenge in focus is to find a material that can efficiently and selectively produce $\mathrm{H}_{2} \mathrm{O}_{2}$ from water by using photo electrochemical production system of $\mathrm{H}_{2} \mathrm{O}_{2}$. Various metal oxides have been used for electrochemical oxidation of water such as $\mathrm{WO}_{3}-\mathrm{BiVO}_{4}{ }^{[111,126,127]} \mathrm{MnOx}^{[108,109]}$ and $\mathrm{TiO}_{2}{ }^{[128-132]}$ These studies reported $\mathrm{BiVO}_{4}$ as the best oxide for $\mathrm{H}_{2} \mathrm{O}_{2}$ production ${ }^{[111,126]}$ along with demonstrating $\mathrm{H}_{2} \mathrm{O}_{2}$ production potential over metal oxides. However, for metal oxides more studies are required about limiting potential of $\mathrm{H}_{2} \mathrm{O}_{2}$ generation and energy barriers. Moreover, there is not enough data present about experimentally and theoretically variation of these oxides in $\mathrm{H}_{2} \mathrm{O}_{2}$ generation efficiency.

Shi, Siahrostami, ${ }^{[133]}$ carried out a study on four different oxides (i.e. $\mathrm{SnO}_{2}, \mathrm{WO}_{3}, \mathrm{BiVO}_{4}$ and $\mathrm{TiO}_{2}$ ) to theoretically investigate the activity trends of these oxides towards water oxidation for $\mathrm{H}_{2} \mathrm{O}_{2}$ production. It was reported that $\mathrm{H}_{2} \mathrm{O}_{2}$ production potential for both measured and calculated onset increases in the sequence of $\mathrm{WO}_{3}, \mathrm{BiVO}_{4}, \mathrm{SnO}_{2}$ and $\mathrm{TiO}_{2}$. A consistent result with previous studies on comparing different metal oxides for $\mathrm{H}_{2} \mathrm{O}_{2}$ production has been obtained ${ }^{[111,126]}$ in which $\mathrm{BiVO}_{4}$ is considered to be the best catalyst among all these four oxides in dark and illuminated two-electron oxidation. The Optimal bias range identified for $\mathrm{BiVO}_{4}$ to produce $\mathrm{H}_{2} \mathrm{O}_{2}$ under illumination $(\sim 1.7 \mathrm{~V}-2.3 \mathrm{~V})$ and in dark $(\sim 2.9 \mathrm{~V}-3.3 \mathrm{~V})$. High faraday efficiency (FE) of $98 \%$ under 1 sun illumination and $70 \%$ under dark condition is achieved by $\mathrm{BiVO}_{4}$.

\section{Activity and selectivity trends of catalyst in electrochemical water oxidation to form $\mathbf{H}_{2} \mathbf{O}_{2}$}

In electrochemical production of $\mathrm{H}_{2} \mathrm{O}_{2}$ catalyst at the electrodes is of crucial importance. The performance of electrochemical devices is dependent on performance of catalyst at the electrode. A electrocatalyst is successful with (a) high activity, operates with high current densities closer to the equilibrium potential to optimize catalyst loading and energy efficiency; (b) high selectivity, ensures high production of $\mathrm{H}_{2} \mathrm{O}_{2}$; and (c) high stability, enables long-lasting performance. Various studies have been carried out in the field of electrocatalysis to find descriptors for the trends in activity and selectivity for electrochemical reactions, and the result leads to a Sabatier volcano, where moderate interactions with the reaction intermediates give rise to highest activity on the. ${ }^{[99,134-138]}$ Above all, new materials with exceeded electrocatalytic performance from the current state-of-the-art can be discovered by the knowledge of this descriptor. ${ }^{[99,136,139,140]}$ Thermodynamics of the competing reactions largely limits the activity and selectivity of the catalyst materials by imposing several criteria ${ }^{[110]}$ hence, synthesis of $\mathrm{H}_{2} \mathrm{O}_{2}$ from water oxidation is a challenging process. Density functional theory (DFT) can be used to calculate the adsorption free energies of relevant intermediates $\mathrm{OH}^{*}, \mathrm{O}^{*}$ and $\mathrm{OOH}^{*}$ 
formed in one- (Equation 14), two- (Equation 10) and four-electron (Equation 13) water oxidation reactions. Shi, Siahrostami ${ }^{[133]}$ shows that the key parameters in determining activity and selectivity towards different oxidation products, $\mathrm{H}_{2} \mathrm{O}_{2}$ (Equation 10), $\mathrm{O}_{2}$ (Equation 13), and $\mathrm{OH}$ radical (Equation 14) are the free energies of $\mathrm{OH}^{*}$ and $\mathrm{O}^{*[110]}$. The free energies of $\mathrm{O}^{*} \mathrm{OH}^{*}$, and $\mathrm{OOH}^{*}$ cab be calculated using DFT.

Shi, Siahrostami ${ }^{[133]}$ studied experimentally and theoretically stable surface, exposed in the $\mathrm{BiVO}_{4}$ crystal structure $^{[141]}$, and uses the computational hydrogen electrode model (CHE). The model exploits that at standard conditions the chemical potential of the proton-electron pair is equal to gas-phase $\mathrm{H}_{2}$. Moreover, the free energies of $\mathrm{O}^{*}, \mathrm{OH}^{*}$ and $\mathrm{OOH}^{*}$ are taken from reported DFT calculations for $\mathrm{WO}_{3}(100), \mathrm{TiO}_{2}$ (110) and $\mathrm{SnO}_{2}$ (110). ${ }^{[10,142-144]}$ The electron energy is shifted by $-e U$ thus taking electron potential into account, where $e$ and $U$ are the elementary charge and the electrode potential, respectively ${ }^{[145]}$. From the thermodynamic point of view, oxygen is evolved by a complete four electron oxidation reaction (Equation 10) followed by strong $\mathrm{OH}$ adsorption energy materials that further oxidize $\mathrm{OH}^{*}$ to $\mathrm{O}^{*}$ and $\mathrm{OOH}^{*}$. Viswanathan, Hansen ${ }^{[110]}$ reported that the lowest potential at which all the reaction steps are downhill in free energy, is the limiting potential for the electrochemical reaction to occur. Electrocatalysts with weak $\mathrm{OH}^{*}$ free energy shows high preference towards the two-electron pathway while will have low selectivity towards the four-electron pathway ${ }^{[133]}$.

A good thermodynamic driving force should be provided by $\mathrm{OH}^{*}$ free energy for two electron pathway towards $\mathrm{H}_{2} \mathrm{O}_{2}$. At the same time, the provided free energy should be strong enough to dissociate the water molecule. Electrocatalyst should have $\Delta G_{O *} \gtrsim 3.5 \mathrm{eV}$ as twice of the equilibrium potential for (Equation 10), is used for $\mathrm{H}_{2} \mathrm{O}_{2}$ formation $(\sim 3.5 \mathrm{eV})$. A lower limit of $\Delta \mathrm{G}_{O H *} \gtrsim \frac{3.5}{2}-\frac{0.28}{2} \sim 1.6 \mathrm{eV}$ is set by $\mathrm{OH}^{*}$ free energy due to $\mathrm{O}^{*}$ and $\mathrm{OH}^{*}$ energies that are generally found to scale $\left(\Delta G_{O *}=2 \Delta G_{O H *}+0.28\right)^{[142]}$. A selective catalyst for $\mathrm{H}_{2} \mathrm{O}_{2}$ evolution indicated by the scaling relation and combined thermodynamic criteria should have $\Delta G_{O H *}$ from $\sim 1.6$ to $2.4 \mathrm{eV}$. This is because the free energy $\mathrm{OH}^{*}$ formed in (Equation 14), sets the upper limit for $\Delta G_{O H}$. Moreover, the reaction is drived towards the $\mathrm{OH}^{*}$ formation by $\mathrm{OH}^{*}$ with too weak free energy of $\Delta G_{O H *} \gtrsim 2.4 \mathrm{eV} . \mathrm{WO}_{3}, \mathrm{SnO}_{2}, \mathrm{BiVO}_{4}$ and $\mathrm{TiO}_{2}$ are suggested by thermodynamic analysis to generate $\mathrm{H}_{2} \mathrm{O}_{2}$ using certain values of $\mathrm{OH}^{*}$ free energy ${ }^{[133]}$. The two electron oxidation reaction (Equation 10) should have high selectivity and activity with low overpotential. Furthermore, a number of catalyst materials deviating from
$\mathrm{O}^{*}$ and $\mathrm{OH}^{*}$ scaling relation are needed to be identified to increase the selectivity region for evolution of $\mathrm{H}_{2} \mathrm{O}_{2}{ }^{[146]}$. The free energy of the $\mathrm{OH}^{*}$ is tuned by controlling the overpotential whereas, binding of $\mathrm{OH}^{*}$ to the catalyst surface governs the overpotential ${ }^{[145]}$.

$\mathrm{H}_{2} \mathrm{O}_{2}$ production activity is a function of the binding of the sole reaction intermediate, $\mathrm{HOO}^{*},{ }^{[95,98]}$ in which the theoretical overpotential for the reaction, $\eta=0$ and adsorption of HOO* should be thermoneutral at the equilibrium potential $\left(U_{\mathrm{O} 2 / \mathrm{H}_{2} \mathrm{O} 2}^{0}=0.7 \mathrm{~V}\right)$ for an ideal catalyst. Lower electrocatalytic activity or additional overpotential will be introduced by weaker or stronger binding to HOO*. Verdaguer-Casadevall, Deiana ${ }^{[103]}$ using well-characterized extended surfaces identified $\mathrm{Pt}-\mathrm{Hg}$ as highly active and selective catalyst for $\mathrm{H}_{2} \mathrm{O}_{2}$ production by density functional theory calculations. It is confirmed by the theoretical predictions that $\mathrm{Pt}-\mathrm{Hg}$ is highly active and selective for oxygen reduction to $\mathrm{H}_{2} \mathrm{O}_{2}$ in both nanoparticles and extended surfaces form ${ }^{[143]}$. An ordered intermetallic (where isolated Pt atoms are surrounded by $\mathrm{Hg}$ ) is formed when $\mathrm{Hg}$ is electrodeposited on $\mathrm{Pt}$ at room temperature ${ }^{[147]}$. Metals like $\mathrm{Cu}, \mathrm{Pd}$, and Ag can be modified by the same electrodeposition procedure. These metals alloy with $\mathrm{Hg}$ and exhibit some stability against potential range of $\mathrm{O}_{2}$ reduction to $\mathrm{H}_{2} \mathrm{O}_{2}$ (i.e., 0 to $0.7 \mathrm{~V}$ ) and dissolution under the acidic conditions. Noticeably, the overpotential is critically affected by the electrode material. $\mathrm{Ag}-\mathrm{Hg}, \mathrm{Pt}-\mathrm{Hg}$, and $\mathrm{Cu}-\mathrm{Hg}$ electrodes show an increasing overpotential whereas, Pd$\mathrm{Hg}$ electrode shows highest current over the lowest overpotential. Pure Ag has similar high activity to that of Pt$\mathrm{Hg}$ for this reaction. Silver has been studied extensively in previous studies whereas, Au based catalyst are found to be less active than all these materials. ${ }^{[58,148,149]} \mathrm{Pd}-\mathrm{Hg}$ has 2 orders of higher magnitude activity while, $\mathrm{Ag}, \mathrm{Pt}-$ $\mathrm{Hg}$, and $\mathrm{Ag}-\mathrm{Hg}$ have improvement in order of magnitude over Au.

Pure metals surfaces have less selectivity to $\mathrm{H}_{2} \mathrm{O}_{2}$ as compared to $\mathrm{Hg}$-modified electrodes. It is anticipated by the research that, in the case of $\mathrm{Cu}-\mathrm{Hg}$, and $\mathrm{Pd}-\mathrm{Hg}$, single atoms of $\mathrm{Cu}$ or $\mathrm{Pd}$ are surrounded by $\mathrm{Hg}$ because of the resemblance of structure of active site to $\mathrm{Pt}-\mathrm{Hg}^{[147]}$. To dissociate $\mathrm{HOO}^{*}$ and to break $\mathrm{O}-\mathrm{O}$ bond for the formation of intermediates $\left(\mathrm{O}^{*}\right.$ and $\left.\mathrm{HO}^{*}\right)$ of 4-electron reduction process at least two contiguous reactive atoms are required. ${ }^{[58,143]}$ Subsequently, O-O bond are made selective for $\mathrm{H}_{2} \mathrm{O}_{2}$ production as monoatomic sites are unable to break them. Over the entire potential range $\mathrm{Ag}-\mathrm{Hg}$ has slightly different cause of its high selectivity at $100 \%$. Rather than an ordered intermetallic, the alloy forms the solid solution as the formation is negative enthalpy at $0.03 \mathrm{eV} /$ atom. The activity of the alloy is slightly lower 
or equal to $\mathrm{Ag}$ because in such a solid solutions there will be some regions close to pure $\mathrm{Hg}$ while others close to pure Ag. It is observed from the DFT calculations that on terrace sites dissociation barrier for $\mathrm{HOO}^{*}\left(\right.$ or $\mathrm{H}_{2} \mathrm{O}_{2}$ ) is much higher than on step sites ${ }^{[44]}$ so, inherently more selective steps should be towards the toward the 4-electron reduction. High selectivity to $\mathrm{H}_{2} \mathrm{O}_{2}$ production can be provided by blocking them with $\mathrm{Hg}$. To be economically competitive high current density per unit mass catalyst and well dispersed catalyst is required in electrochemical $\mathrm{H}_{2} \mathrm{O}_{2}$ production and industrial implementation. ${ }^{[102,150]}$ Verdaguer-Casadevall, Deiana ${ }^{[103]}$ mentioned that out of other catalysts reported thus for, Pd-Hg has higher activity. Compared to the current state-of-the-art ${ }^{[58,95]}$ significant improvements in selectivity, efficiency and cost of $\mathrm{H}_{2} \mathrm{O}_{2}$ producing devices can be brought about by the arrangement of either catalyst ${ }^{[151]}$. Higher activity per mass of precious metals can be achieved by fine tuning of particle composition, size and shape $\mathrm{e}^{[152-156]}$. The oxygen reduction concept of tuning the activity and selectivity of the catalyst can be used in selective oxidation of hydrocarbons ${ }^{[157]}$ or $\mathrm{CO}_{2}$ reduction. ${ }^{[158,159]}$

\section{Electrocatalytic detection of $\mathrm{H}_{2} \mathrm{O}_{2}$}

$\mathrm{H}_{2} \mathrm{O}_{2}$ is extensively used in many fields, has great importance and is a by-product of many oxidase enzymes. Moreover, $\mathrm{H}_{2} \mathrm{O}_{2}$ is referred as Reactive Oxygen Species (ROS) so it develops great interest in medical field. An accurate determination of $\mathrm{H}_{2} \mathrm{O}_{2}$ is necessary because the excessive accumulation of it can cause serious damages like, DNA fragmentation and tissue damage ${ }^{[160]}$. Currently, many methods including fluorescence ${ }^{[161]}$, colorimetry, titrimetry, electrochemical, Chemiluminescence ${ }^{[162]}$ and spectrophotometry ${ }^{[163]}$ have been used for the quantitative determination of $\mathrm{H}_{2} \mathrm{O}_{2}$. Compared to all these methods electrochemical method is very selective, sensitive, easy to prepare, requires less experienced staff, less time consuming and less expensive. For determination of $\mathrm{H}_{2} \mathrm{O}_{2}$ electrochemical sensors including enzymatic $^{[164]}$ and non-enzymatic ${ }^{[165]}$ have been developed so for. Compared to non-enzymatic sensors, electrochemical sensors based on enzymes are more selective because they are substrate specific for converting them into product. Whereas, in case of stability, enzymatic electrochemical sensors shows long term stability. ${ }^{[166,167]}$ Scientists have been working to overcome these drawbacks by developing more sensitive, stable and selective $\mathrm{H}_{2} \mathrm{O}_{2}$ electrochemical sensors.

Recently, the most active electrochemical sensors being in use are based on graphene. Graphene has two-dimensional lattice nanostructure having two- dimensional carbon atoms arrange in a single plate of $\mathrm{sp}^{2}$ hybrid. Graphene based electrochemical sensors/biosensors have unique mechanical and thermal properties, high stability, electronic conductivity and large surface area. The oxidized graphene (GO) is hydrophilic and can works easily through noncovalent and covalent bonding when combined with carboxyl groups, epoxy and hydroxyl ions. Due to low conductivity of GO than reduced graphene oxide ( $\mathrm{rGO})$ it was reduced to $\mathrm{rGO}{ }^{[168,169]} \mathrm{rGO}$ is functionalized and dispersed in aqueous solution by mean of oxygen containing functional groups attached to it ${ }^{[170]}$. Different optical, electronic, and catalytic properties of noble metal nanoparticles have made them modifier for electrodes. This could also be because of their good electron transfer rate, remarkable stabilities and large surface area. A large improvement have been seen by using graphene ${ }^{[171]}$, titanium dioxide ${ }^{[172]}$, carbon nanotubes ${ }^{[173]}$, and silica ${ }^{[174]}$ as supporting materials for electrochemical communication between these nanomaterials and analyte. Though, working electrodes needs necessary improvements in selectivity and sensitivity of these nanoparticles using suitable nanocomposite materials. Moreover, for improving reliable, accurate and low cost electrochemical sensors, particularly significant fabrication of new nanocomposites is necessary.

Unlike monometallic nanoparticles, many of the bimetallic nanoparticles have excellent electrochemical properties that make them the center of interest and are referred for electrochemical determination of $\mathrm{H}_{2} \mathrm{O}_{2}$ by the scientists. Various studies reported bimetallic nanoparticles for electrochemical detection of $\mathrm{H}_{2} \mathrm{O}_{2}$ such as Fe@Pt core-shell ${ }^{[175]}$, Au-Pd bimetallic nanoparticles ${ }^{[176]}, \mathrm{Ag}-\mathrm{Au} / \mathrm{Cu} 2 \mathrm{O}$ nanocubes ${ }^{[177]}$, Pt$\mathrm{Ag}^{[178]}$ and $\mathrm{Pt}-\mathrm{Au}^{[179]}$. These studies show remarkable electrochemical response of $\mathrm{H}_{2} \mathrm{O}_{2}$ towards bimetallic nanocatalysts as compared to monometallic. Guler, Turkoglu ${ }^{[180]}$ used Pd@Ag bimetallic nanoparticles for electrochemical determination of $\mathrm{H}_{2} \mathrm{O}_{2}$ supported on 3aminopropyltriethoxysilane (APTES) functionalized reduced graphene oxide. Because of synergistic effect, the constructed sensor shows excellent stability, selectivity and sensitivity (1307.46 $\left.\mu \mathrm{A} \cdot \mathrm{mM}^{-1} . \mathrm{cm}^{-2}\right)$ towards the reduction of $\mathrm{H}_{2} \mathrm{O}_{2}$ and can be used for determination of $\mathrm{H}_{2} \mathrm{O}_{2}$ as an encouraging material.

Most of sensors used for $\mathrm{H}_{2} \mathrm{O}_{2}$ determination, exhibit their own technical drawbacks such as being complicated, time consuming or requiring expensive instrumentation. However, printed electrochemical sensors have proved themselves as successful for detection of many compounds based on their selectivity, sensitivity, fast response, cost-effectiveness and ease of use. Electrocat- 
alytic detection of $\mathrm{H}_{2} \mathrm{O}_{2}$ has been performed by various materials such as redox polymers, redox proteins and transition metals. ${ }^{[131,192-194]}$ Prussian blue (PB) or Ferric hexacyanoferrate has been referred as an "artificial peroxidase" $[195]$.

Electrochemical reduction of Prussian blue (PB) forms Prussian white (PW), which at low potential (around $0 \mathrm{~V}$ vs. $\mathrm{Ag} / \mathrm{AgCl}$ ) catalyzes the reduction of hydrogen peroxide. This characteristic allows PW to work in the presence of a wide range of interferences. PB cab be produced by several methods mentioned in the literature, which are based on electrochemical techniques for deposition $^{[196]}$ or in situ chemical deposition ${ }^{[197]}$ on electrode surfaces. In electrochemical sensor field an increasing attention has been received by Prussian blue nanoparticles (PBNPs) because of its increased electrochemical properties and enhanced surface to volume ratio. The type of chemical environment for characterization and synthesis can influence the properties of nanoparticles.

Hence, PBNPs have been developed characterized by particular properties through alone production ${ }^{[198]}$ or in the presence of other nanomaterials ${ }^{[199,200]}$ in order to constitute a hybrid nanocomposite. Nowadays the most powerful deposition technology used for fabrication of sensors is Inkjet printing. This deposition methodology is most widely used fabrication process that has ability to deliver picolitre drop volumes of precisely patterned ink $^{[201-203]}$, and using nanomaterial-based inks in inkjet printing is a key technology for printed electronics ${ }^{[204]}$.

Cinti, Arduini ${ }^{[205]}$ develops a simple and low cost novel amperometric hydrogen peroxide electrochemical sensor with an excellent performance for the determination of $\mathrm{H}_{2} \mathrm{O}_{2}$. On screen-printed electrodes PBNPs was deposited using inkjet printing. The experimental results showed excellent electrocatalytic activity and reproducibility of the nanocomposites towards the electrochemical reduction of $\mathrm{H}_{2} \mathrm{O}_{2}$. To fabricate the sensing devices for $\mathrm{H}_{2} \mathrm{O}_{2} \mathrm{Hu}$, Lin ${ }^{[206]}$ also reported PBNPs based inkjet printing process. However, regarding the determination of $\mathrm{H}_{2} \mathrm{O}_{2}$, Cinti, Arduini ${ }^{[205]}$ reported significant improvements in terms of detection limit, sensitivity, reproducibility and linear range.

\section{Conclusion}

In summary, hydrogen peroxide with a long manufacturing history is a nontoxic and versatile commodity chemical which is completely miscible in water. Industrial production of $\mathrm{H}_{2} \mathrm{O}_{2}$ went through different stages and new research has been carried to find innovative new processes and materials based on production of $\mathrm{H}_{2} \mathrm{O}_{2}$. A batch process, Anthraquinone is an old production pro- cess of $\mathrm{H}_{2} \mathrm{O}_{2}$ carried out in large facilities with different disadvantage in steps of separation involved in purifying $\mathrm{H}_{2} \mathrm{O}_{2}$ from the organic impurities and side reactions occurring in the process which requires hydrogenation of the catalyst and regeneration of the solution. The direct synthesis process of $\mathrm{H}_{2} \mathrm{O}_{2}$ is a promising alternative of anthraquinone process which involves direction reaction of $\mathrm{H}_{2}$ and $\mathrm{O}_{2}$ in a liquid medium in the presence of catalyst enabling the production in continuous mode. Environmental regulations and the concerns have been set to the increasing demand of the $\mathrm{H}_{2} \mathrm{O}_{2}$ in recent years. In particular literature review of about last two decades we emphasize that to overcome an increased pressure on energy resources caused by continued increase in global population and economic development; on site electrochemical production process of $\mathrm{H}_{2} \mathrm{O}_{2}$ must be considered with no side waste generation.

Electrochemical devices ${ }^{[56]}$ and electrolysis of water $^{[60]}$ operated at ambient temperature and pressure ${ }^{[90]}$ in small plants can be helpful in storage, electrochemical energy conversion process, and in transformation, as they require minimal capital investment. In electrochemical production of $\mathrm{H}_{2} \mathrm{O}_{2}$ catalyst at the electrodes is of crucial importance so presently, the main challenge in focus is to find a material that can efficiently and selectively produce $\mathrm{H}_{2} \mathrm{O}_{2}$. Synthesis of $\mathrm{H}_{2} \mathrm{O}_{2}$ from water oxidation is a challenging process as the activity and selectivity of the catalyst materials is largely limited by imposing several criteria by thermodynamics of the competing reactions ${ }^{[110]}$. Moreover, to increase the selectivity region for $\mathrm{H}_{2} \mathrm{O}_{2}$ production, a number of catalyst materials deviating from $\mathrm{O}^{*}$ and $\mathrm{OH}^{*}$ scaling relation are needed to be identified ${ }^{[146]}$. We anticipate from the previous studies and theoretical predictions that $\mathrm{Pt}-\mathrm{Hg}$ is highly active and selective for oxygen reduction to $\mathrm{H}_{2} \mathrm{O}_{2}$ in both nanoparticles and extended surfaces whereas Au based catalyst are found to be less active. In particular we emphasize that pure metals surfaces have less selectivity to $\mathrm{H}_{2} \mathrm{O}_{2}$ as compared to Hg-modified electrodes.

\section{Acknowlegdment}

This work was supported by the National Natural Science Foundation of China (21705056), the Young Taishan Scholars Program (tsqn201812080), the Natural Science Foundation of Shandong Province (ZR2019YQ10, ZR2017MB022, ZR2018BB057, ZR2018PB009) and the Open Funds of the State Key Laboratory of Electroanalytical Chemistry (SKLEAC201901). 
Table 1. A comprehensive summary of $\mathrm{H}_{2} \mathrm{O}_{2}$ production, catalytic activity, selectivity and stability from ORR

\begin{tabular}{|c|c|c|c|c|c|c|c|c|}
\hline Catalyst & Electrolytes & $\mathrm{pH}$ & $\begin{array}{c}\mathrm{H}_{2} \mathrm{O}_{2} \text { Yield } \\
\text { (9\%)/ production rate } \\
\text { (mmolh } \\
\left.\text { (mmol- } \mathrm{g}^{-1}\right)\end{array}$ & $\begin{array}{l}\text { Potential vs } \\
\text { SCE/RHE }\end{array}$ & $\begin{array}{l}\text { Catalytic } \\
\text { Activity }\end{array}$ & $\begin{array}{l}\text { Catalytic } \\
\text { Selectivity }\end{array}$ & $\begin{array}{l}\text { Catalytic } \\
\text { Stability }\end{array}$ & Reference \\
\hline $\mathrm{Fe}, \mathrm{O}_{4} /$ graphene & $1 \mathrm{MKOH}$ & Alkaline & $>60 \%$ & $\begin{array}{l}-0.2 \text { to }-0.7 \mathrm{~V} \\
\text { vs SCE }\end{array}$ & High & High & High & [181] \\
\hline $\begin{array}{l}\text { Fe: } \mathrm{O}_{4} \text { - Printex } \\
\text { Hierarchically porous }\end{array}$ & $\begin{array}{c}1 \mathrm{MKOH} \\
\mathrm{O}_{2} / \text { Ar saturated }\end{array}$ & $\begin{array}{l}\text { Alkaline } \\
\text { Acidic }\end{array}$ & $\begin{array}{c}360 \% \\
395.7-110.2\end{array}$ & $\begin{array}{l}-0.2 \text { to }-0.7 \mathrm{~V} \\
\mathrm{Vs} S \mathrm{SCE} \\
-0.5 \mathrm{~V} \mathrm{vs}\end{array}$ & High & $\mathrm{High}$ & High & [181] \\
\hline carbon $\left(\mathrm{HPC}_{24}\right)$ & solution & $\mathrm{pH} \sim 1-7$ & $70.8-81.8 \%$ & $\begin{array}{l}\text { RHE } \\
\sim 0.7 \mathrm{~V} \text { vs }\end{array}$ & High & Good & - & [182] \\
\hline Au-Pd nanoparticles & $0.1 \mathrm{MHClO}_{4}$ & Acidic & $95 \%$ & & Low & Good & - & [183] \\
\hline $\mathrm{Au}_{2}\left(\mathrm{SC}_{12} \mathrm{H}_{2}\right)_{1 \mathrm{x}}$ & $0.1 \mathrm{M} \mathrm{KOH}$ & Alkaline & $\sim 90 \%$ & $S C E$ & High & High & High & [184] \\
\hline $\mathrm{PtH} g 4$ & $0.1 \mathrm{MHClO}_{4}$ & Acidic & $96 \%$ & $0.6 \mathrm{~V}$ vs $\mathrm{RHE}$ & Optimal & $\begin{array}{l}\text { Decrease } \\
\text { below } 0.2 \mathrm{~V}\end{array}$ & Poor & [95] \\
\hline $\mathrm{CNTs}$ and $0-\mathrm{CNTs}$ & $\begin{array}{l}0.1 \mathrm{MKOH} \text { or } \\
0.1 \mathrm{M} \text { phosphate } \\
\text { buffered saline }\end{array}$ & $\begin{array}{l}\text { Alkaline } \\
\mathrm{pH} \sim 13\end{array}$ & $90 \%$ & $1.2 \mathrm{~V}$ vs $\mathrm{RHE}$ & High & High & Good & [185] \\
\hline meso-BMP-800 & $0.1 \mathrm{MHClO}_{4}$ & Acidic & $65.15 \%$ & $\begin{array}{l}0.1 \mathrm{~V} \mathrm{vs} \mathrm{RHE} \\
200 \mathrm{mV} \mathrm{Vs}\end{array}$ & High & Good & _ & [59] \\
\hline $\begin{array}{c}\mathrm{CeO}_{2} / \mathrm{C} \\
\text { commercial }\end{array}$ & $1 \mathrm{MNaOH}$ & Alkaline & $44 \%$ & $\begin{array}{l}\text { RHE } \\
\sim 1.6 \mathrm{~V} \text { vs }\end{array}$ & High & - & - & [186] \\
\hline $\begin{array}{l}\text { mesoporous carbon, } \\
\text { CNIK-3 }\end{array}$ & $0.1 \mathrm{M} \mathrm{KOH}$ & Alkaline & $>90 \%$ & RHE & High & High & Excellent & [187] \\
\hline Printex L 6 & $1 \mathrm{MNaOH}$ & Alkaline & $88 \%$ & - & High & - & - & [188] \\
\hline $\begin{array}{l}\text { Vulcan } \mathrm{XC}-72 \mathrm{R} \\
\text { Printex } 6 \mathrm{~L} \text { carbon }\end{array}$ & $1 \mathrm{MNaOH}$ & Alkaline & $51 \%$ & - & Optimal & - & - & [188] \\
\hline $\begin{array}{l}\text { containing co balt (II) } \\
\text { phthalocy anine (CoPc) }\end{array}$ & $\begin{array}{c}0.1 \mathrm{M} \mathrm{H}_{2} \mathrm{SO}_{4} \\
\mathrm{~K}_{2} \mathrm{SO}_{4} \\
0.5 \mathrm{MH}_{3} \mathrm{SO}_{4}, 01\end{array}$ & $\begin{array}{l}\text { Alkaline, } \\
\text { Acidic, }\end{array}$ & $81.5 \%$ & $+1.0 \mathrm{~V} v \mathrm{vs}$ & - & - & High & [189] \\
\hline nitrogen-doped CMIK-3 & $\begin{array}{c}\mathrm{Na}_{\mathrm{NO}}, \mathrm{KOH} \\
\mathrm{KH}_{3} \mathrm{PO}_{4}\end{array}$ & $\begin{array}{l}\text { Acidic, } \\
\text { Alkaline }\end{array}$ & - & $1.2 \mathrm{~V}$ vs RHE & High & High & - & [190] \\
\hline $\operatorname{mrGO}, \mathrm{F}-\operatorname{mrGO}$ & $\begin{array}{c}0.1 \mathrm{MKOH}, 001 \mathrm{M} \\
\mathrm{HO}_{2}^{-}\end{array}$ & Alkaline & - & $\begin{array}{l}0.815 \mathrm{~V} \text { vs } \\
\text { RHE }\end{array}$ & High & High & High & [191] \\
\hline
\end{tabular}

\section{References}

[1] Thénard LJ. Observations sur des nouvelles combinaisons entre l'oxigne et divers acides. Ann Chim Phys, 1818, 8: 306-312.

[2] Thenard L. Nouvelles observations sur les acides et les oxides oxigenes. Annales de chimie et de physique, 1818.

[3] Meidinger H. Ueber voltametrische Messungen. Justus Liebigs Annalen der Chemie, 1853, 88(1): 57-81. https://doi.org/10.1002/jlac.18530880103

[4] Manchot W. Ueber Sauerstoffactivirung. Justus Liebigs Annalen der Chemie, 1901, 314(1-2): 177-199. https://doi.org/10.1002/jlac.19013140117

[5] Walton JH and Filson GW. The direct preparation of hydrogen peroxide in a high concentration. Journal of the American Chemical Society, 1932, 54(8): 3228-3229. https://doi.org/10.1021/ja01347a026

[6] Riedl H and Pfleiderer G. US Patent, 2,158,525 (1939). Google Scholar.

[7] Goor G, Glenneberg J and Jacobi S. Hydrogen peroxide. Ullmann's Encyclopedia of Industrial Chemistry, 2000. https://doi.org/10.1002/14356007.a13_443
[8] Teles JH, Hermans I, Franz G, et al. Oxidation, Ullmann's Encyclopedia of Industrial Chemistry, 2000: 1-103. https://doi.org/10.1002/14356007.a18_261.pub2

[9] Bajpai P. Pulp and Paper Industry: Microbiological Issues in Papermaking, 2015. https://doi.org/10.1016/B978-0-12-803408-8.00002-0

[10] Ciriminna R, Albanese L, Meneguzzo F, et al. Hydrogen peroxide: A Key chemical for today's sustainable development. ChemSusChem, 2016, 9(24): 3374-3381. https://doi.org/10.1002/cssc.201600895

[11] Ranganathan S and Sieber V. Recent Advances in the Direct Synthesis of Hydrogen Peroxide Using Chemical CatalysisA Review. Catalysts, 2018, 8(9): 379. https://doi.org/10.3390/catal8090379

[12] Hage R and Lienke A. Applications of transition-metal catalysts to textile and wood-pulp bleaching. Angewandte Chemie International Edition, 2006, 45(2): 206-222. https://doi.org/10.1002/anie.200500525

[13] Agarwal N, Freakley SJ, McVicker RU, et al. Aqueous AuPd colloids catalyze selective $\mathrm{CH}_{4}$ oxidation to $\mathrm{CH}_{3} \mathrm{OH}$ with $\mathrm{O}_{2}$ under mild conditions. Science, 2017, 358(6360): 223-227. https://doi.org/10.1126/science.aan6515 
[14] Brillas E, Sirs I and Oturan MA. Electro-Fenton process and related electrochemical technologies based on Fenton's reaction chemistry. Chemical reviews, 2009, 109(12): 65706631. https://doi.org/10.1021/cr900136g

[15] Yi Y, Wang L, Li G, et al. A review on research progress in the direct synthesis of hydrogen peroxide from hydrogen and oxygen: noble-metal catalytic method, fuel-cell method and plasma method. Catalysis Science \& Technology, 2016, 6(6): 1593-1610. https://doi.org/10.1039/C5CY01567G

[16] Campos-Martin JM, Blanco-Brieva G and Fierro JL. Hydrogen peroxide synthesis: an outlook beyond the anthraquinone process. Angewandte Chemie International Edition, 2006, 45(42): 6962-6984. https://doi.org/10.1002/anie.200503779

[17] Weidner E and Pflaum H. Leitprojekt "Strom als Rohstoff", in Ressourceneffizienz, 2017: 197-238. https://doi.org/10.1007/978-3-662-52889-1_11

[18] Nishimi T, Kamachi T, Kato K, et al. Mechanistic study on the production of hydrogen peroxide in the anthraquinone process. European Journal of Organic Chemistry, 2011, 2011(22): 4113-4120. https://doi.org/10.1002/ejoc.201100300

[19] Lagow RJ and Margrave JL. Direct fluorination: a "new" approach to fluorine chemistry. Progress in Inorganic Chemistry, 1979: 161-210. https://doi.org/10.1002/9780470166277.cH\$_3\$

[20] Goor G and Kunkel WO. Weiberg, Ullmann's Encyclopedia of Industrial Chemistry, vol. A13, VCH Weinheim, 1989.

[21] Santacesaria E, Di Serio M, Velotti R, et al. Hydrogenation of the aromatic rings of 2-ethylanthraquinone on palladium catalyst. Journal of molecular catalysis, 1994, 94(1): 37-46. https://doi.org/10.1016/0304-5102(94)87028-4

[22] Fajt V, Kurc L and Cervenv L. The effect of solvents on the rate of catalytic hydrogenation of 6-ethyl-1, 2, 3, 4tetrahydroanthracene-9, 10-dione. International Journal of Chemical Kinetics, 2008, 40(5): 240-252. https://doi.org/10.1002/kin.20309

[23] Albers RE, Nyström M, Siverström M, et al. Development of a monolith-based process for $\mathrm{H}_{2} \mathrm{O}_{2}$ production: from idea to large-scale implementation. Catalysis Today, 2001, 69(1-4): 247-252. https://doi.org/10.1016/S0920-5861(01)00376-5

[24] Hou Y, Wang Y, He F, et al. Liquid phase hydrogenation of 2-ethylanthraquinone over La-doped Ni-B amorphous alloy catalysts. Materials Letters, 2004, 58(7-8): 1267-1271. https://doi.org/10.1016/j.matlet.2003.09.019

[25] Sheldon R and JK Kochi. Metal Catalyzed Oxidations of Organic Compounds. Academic Press, New York, 1981: 75. https://doi.org/10.1016/B978-0-12-639380-4.50007-5

[26] Berglin T and Schoeoen NH. Selectivity aspects of the hydrogenation stage of the anthraquinone process for hydrogen peroxide production. Industrial \& Engineering Chemistry Process Design and Development, 1983, 22(1): 150153.

https://doi.org/10.1021/i200020a024
[27] Santacesaria E, Ferro R, Ricci S, et al. Kinetic aspects in the oxidation of hydrogenated 2-ethyltetrahydroanthraquinone. Industrial \& engineering chemistry research, 1987, 26(1): 155-159. https://doi.org/10.1021/ie00061a029

[28] Edwards JK, Solsona B, Ntainjua E, et al. Switching off hydrogen peroxide hydrogenation in the direct synthesis process. Science, 2009, 323(5917): 1037-1041. https://doi.org/10.1126/science.1168980

[29] Ford DC, Nilekar AU, Xu Y, et al. Partial and complete reduction of $\mathrm{O}_{2}$ by hydrogen on transition metal surfaces. Surface Science, 2010, 604(19-20): 1565-1575. https://doi.org/10.1016/j.susc.2010.05.026

[30] Kralik M and Biffis A. Catalysis by metal nanoparticles supported on functional organic polymers. Journal of Molecular Catalysis A: Chemical, 2001, 177(1): 113-138. https://doi.org/10.1016/S1381-1169(01)00313-2

[31] Liu B, Qiao M, Wang J, et al. Highly selective amorphous Ni-Cr-B catalyst in 2-ethylanthraquinone hydrogenation to 2-ethylanthrahydroquinone. Chemical Communications, 2002, 11: 1236-1237. https://doi.org/10.1039/b202499n

[32] Chen X, Hu H, Liu B, et al. Selective hydrogenation of 2-ethylanthraquinone over an environmentally benign $\mathrm{Ni}$ B/SBA-15 catalyst prepared by a novel reductantimpregnation method. Journal of Catalysis, 2003, 220(1): 254-257. https://doi.org/10.1016/j.jcat.2003.07.007

[33] Edwards JK, Freakley SJ, Lewis RJ, et al. Advances in the direct synthesis of hydrogen peroxide from hydrogen and oxygen. Catalysis Today, 2015, 248: 3-9. https://doi.org/10.1016/j.cattod.2014.03.011

[34] Samanta C. Direct synthesis of hydrogen peroxide from hydrogen and oxygen: An overview of recent developments in the process. Applied Catalysis A: General, 2008, 350(2): 133-149. https://doi.org/10.1016/j.apcata.2008.07.043

[35] Henkel H and Weber W. Manufacture of hydrogen peroxid. Google Patents, 1914.

[36] Edwards JK, Freakley SJ, Carley AF, et al. Strategies for designing supported gold-palladium bimetallic catalysts for the direct synthesis of hydrogen peroxide. Accounts of chemical research, 2013, 47(3): 845-854. https://doi.org/10.1021/ar400177c

[37] Lunsford $\mathrm{JH}$, The direct formation of $\mathrm{H}_{2} \mathrm{O}_{2}$ from $\mathrm{H}_{2}$ and $\mathrm{O}_{2}$ over palladium catalysts. Journal of catalysis, 2003, 216(12): 455-460. https://doi.org/10.1016/S0021-9517(02)00070-2

[38] Freakley SJ, He Q, Harrhy JH, et al. Palladium-tin catalysts for the direct synthesis of $\mathrm{H}_{2} \mathrm{O}_{2}$ with high selectivity. Science, 2016, 351(6276): 965-968. https://doi.org/10.1126/science.aad5705

[39] Edwards JK, Carley AF, Herzing AA, et al. Direct synthesis of hydrogen peroxide from $\mathrm{H}_{2}$ and $\mathrm{O}_{2}$ using supported AuPd catalysts. Faraday Discussions, 2008, 138: 225-239. https://doi.org/10.1039/B705915A

[40] Edwards JK, Thomas A, Carley AF, et al. Au-Pd supported nanocrystals as catalysts for the direct synthesis of hydrogen peroxide from $\mathrm{H}_{2}$ and $\mathrm{O}_{2}$. Green Chemistry, 2008, 10(4): 388-394. https://doi.org/10.1039/B714553P 
[41] Ntainjua E, Edwards JK, Carley AF, et al. The role of the support in achieving high selectivity in the direct formation of hydrogen peroxide. Green Chemistry, 2008, 10(11): 1162-1169. https://doi.org/10.1039/b809881f

[42] Ntainjua NE, Piccinini M, Pritchard JC, et al. Effect of halide and acid additives on the direct synthesis of hydrogen peroxide using supported gold-palladium catalysts. ChemSusChem: Chemistry \& Sustainability Energy \& Materials, 2009, 2(6): 575-580. https://doi.org/10.1002/cssc. 200800257

[43] Edwards JK, Pritchard J, Piccinini M, et al. The effect of heat treatment on the performance and structure of carbonsupported Au-Pd catalysts for the direct synthesis of hydrogen peroxide. Journal of catalysis, 2012, 292: 227-238. https://doi.org/10.1016/j.jcat.2012.05.018

[44] Rankin RB and Greeley J. Trends in selective hydrogen peroxide production on transition metal surfaces from first principles. Acs Catalysis, 2012, 2(12): 2664-2672. https://doi.org/10.1021/cs3003337

[45] Blanco-Brieva G, Capel-Sanchez MC, De Frutos MP, et al. New two-step process for propene oxide production (HPPO) based on the direct synthesis of hydrogen peroxide. Industrial \& Engineering Chemistry Research, 2008, 47(21): 8011-8015. https://doi.org/10.1021/ie800245r

[46] Jones CW and Clark JH. Introduction to the preparation and properties of hydrogen peroxide. Applications of Hydrogen Peroxide and Derivatives, 1999: 1-36. https://doi.org/10.1039/9781847550132-00001

[47] Zhou B. Nano-Enabled Catalysts for the Commercially Viable Production of $\mathrm{H}_{2} \mathrm{O}_{2}$. Lawrenceville (NJ), 2007: 26.

[48] Burch R and Ellis P. An investigation of alternative catalytic approaches for the direct synthesis of hydrogen peroxide from hydrogen and oxygen. Applied Catalysis B: Environmental, 2003, 42(2): 203-211. https://doi.org/10.1016/S0926-3373(02)00232-1

[49] Flaherty DW. Direct Synthesis of $\mathrm{H}_{2} \mathrm{O}_{2}$ from $\mathrm{H}_{2}$ and $\mathrm{O}_{2}$ on Pd Catalysts: Current Understanding, Outstanding Questions, and Research Needs. ACS Publications, 2018. https://doi.org/10.1021/acscatal.7b04107

[50] Liu Q and Lunsford JH. Controlling factors in the direct formation of $\mathrm{H}_{2} \mathrm{O}_{2}$ from $\mathrm{H}_{2}$ and $\mathrm{O}_{2}$ over a $\mathrm{Pd} / \mathrm{SiO}_{2}$ catalyst in ethanol. Applied Catalysis A: General, 2006, 314(1): 94100 . https://doi.org/10.1016/j.apcata.2006.08.014

[51] Centi G, Perathoner S and Abate S. Direct synthesis of hydrogen peroxide: recent advances. Modern Heterogeneous Oxidation Catalysis: Design, Reactions and Characterization, 2009: 253-287. https://doi.org/10.1002/9783527627547.ch8

[52] Moreno T, Garca-Serna J and Cocero MJ. Direct synthesis of hydrogen peroxide in methanol and water using $\mathrm{scCO}_{2}$ and $\mathrm{N}_{2}$ as diluents. Green Chemistry, 2010, 12(2): 282-289. https://doi.org/10.1039/B916788A

[53] Wilson NM and Flaherty DW. Mechanism for the direct synthesis of $\mathrm{H}_{2} \mathrm{O}_{2}$ on Pd clusters: heterolytic reaction pathways at the liquid-solid interface. Journal of the American Chemical Society, 2015, 138(2): 574-586. https://doi.org/10.1021/jacs.5b10669
[54] Wilson NM, Priyadarshini P, Kunz S, et al. Direct synthesis of $\mathrm{H}_{2} \mathrm{O}_{2}$ on $\mathrm{Pd}$ and $\mathrm{Au} \times \mathrm{Pd} 1$ clusters: Understanding the effects of alloying Pd with Au. Journal of Catalysis, 2018, 357: 163-175. https://doi.org/10.1016/j.jcat.2017.10.028

[55] Chorkendorff I and Niemantsverdriet J. Environmental Catalysis. Concepts of Modern Catalysis and Kinetics, Wiley-VCH Verlag GmbH \& Co KGaA, Weinheim, Germany, 2003: 377-391.

[56] Kotrel S and Bruninger S. Industrial Electrocatalysis. Handbook of Heterogeneous Catalysis: Online, 2008: 19361958.

https://doi.org/10.1002/9783527610044.hetcat0103

[57] Yamanaka I, Onizawa T, Takenaka S, et al. Direct and continuous production of hydrogen peroxide with $93 \%$ selectivity using a fuel-cell system. Angewandte Chemie, 2003, 115(31): 3781-3783. https://doi.org/10.1002/ange.200351343

[58] Jirkovsky JS, Panas I, Ahlberg E, et al. Single atom hotspots at Au-Pd nanoalloys for electrocatalytic $\mathrm{H}_{2} \mathrm{O}_{2}$ Production. Journal of the American Chemical Society, 2011, 133(48): 19432-19441. https://doi.org/10.1021/ja206477z

[59] Fellinger TP, Haschée F, Strasser P, et al. Mesoporous nitrogen-doped carbon for the electrocatalytic synthesis of hydrogen peroxide. Journal of the American Chemical Society, 2012, 134(9): 4072-4075. https://doi.org/10.1021/ja300038p

[60] Li X, Hao X, Abudula A, et al. Nanostructured catalysts for electrochemical water splitting: current state and prospects. Journal of Materials Chemistry A, 2016, 4(31): 11973 12000. https://doi.org/10.1039/C6TA02334G

[61] Chen G, Bare SR and Mallouk TE. Development of supported bifunctional electrocatalysts for unitized regenerative fuel cells. Journal of the Electrochemical Society, 2002, 149(8): A1092-A1099. https://doi.org/10.1149/1.1491237

[62] Suen NT, Hung SF, Quan Q, et al. Electrocatalysis for the oxygen evolution reaction: recent development and future perspectives. Chemical Society Reviews, 2017, 46(2): 337 365.

https://doi.org/10.1039/C6CS00328A

[63] Tahir M, Pan L, Idrees F, et al. Electrocatalytic oxygen evolution reaction for energy conversion and storage: A comprehensive review. Nano Energy, 2017, 37: 136-157. https://doi.org/10.1016/j.nanoen.2017.05.022

[64] Cherevko S, Geiger S, Kasian O, et al. Oxygen and hydrogen evolution reactions on $\mathrm{Ru}, \mathrm{RuO}_{2}, \mathrm{Ir}$, and $\mathrm{IrO}_{2}$ thin film electrodes in acidic and alkaline electrolytes: A comparative study on activity and stability. Catalysis Today, 2016, 262: $170-180$. https://doi.org/10.1016/j.cattod.2015.08.014

[65] Malkhandi S, Trinh P, Manohar AK, et al. Electrocatalytic activity of transition metal oxide-carbon composites for oxygen reduction in alkaline batteries and fuel cells. Journal of The Electrochemical Society, 2013, 160(9): F943-F952. https://doi.org/10.1149/2.109308jes 
[66] Hardin WG, Mefford JT, Slanac DA, et al. Tuning the electrocatalytic activity of perovskites through active site variation and support interactions. Chemistry of Materials, 2014, 26(11): 3368-3376. https://doi.org/10.1021/cm403785q

[67] Mohamed R, Cheng X, Fabbri E, et al. Electrocatalysis of perovskites: the influence of carbon on the oxygen evolution activity. Journal of The Electrochemical Society, 2015, 162(6): 579-586. https://doi.org/10.1149/2.0861506jes

[68] Minguzzi A, Alpuche-Aviles MA, Lpez JR, et al. Screening of oxygen evolution electrocatalysts by scanning electrochemical microscopy using a shielded tip approach. Analytical chemistry, 2008, 80(11): 4055-4064. https://doi.org/10.1021/ac8001287

[69] Chen X, Botz AJ, Masa J, et al. Characterisation of bifunctional electrocatalysts for oxygen reduction and evolution by means of SECM. Journal of Solid State Electrochemistry, 2016, 20(4): 1019-1027. https://doi.org/10.1007/s10008-015-3028-z

[70] Macounov K, Makarova M, Jirkovskv J, et al. Parallel oxygen and chlorine evolution on $\mathrm{Ru} 1-\mathrm{xNixO}_{2}-\mathrm{y}$ nanostructured electrodes. Electrochimica Acta, 2008, 53(21): 61266134. https://doi.org/10.1016/j.electacta.2007.11.014

[71] Zeradjanin AR, Menzel N, Schuhmann W, et al. On the faradaic selectivity and the role of surface inhomogeneity during the chlorine evolution reaction on ternary Ti-RuIr mixed metal oxide electrocatalysts. Physical Chemistry Chemical Physics, 2014, 16(27): 13741-13747. https://doi.org/10.1039/C4CP00896K

[72] Pizzutilo E, Geiger S, Grote JP, et al. On the need of improved accelerated degradation protocols (ADPs): examination of platinum dissolution and carbon corrosion in half-cell tests. Journal of the electrochemical society, 2016, 163(14): 1510-1514. https://doi.org/10.1149/2.0731614jes

[73] Amin HM and Baltruschat H. How many surface atoms in $\mathrm{Co}_{3} \mathrm{O}_{4}$ take part in oxygen evolution? Isotope labeling together with differential electrochemical mass spectrometry. Physical Chemistry Chemical Physics, 2017, 19(37): 25527-25536. https://doi.org/10.1039/C7CP03914J

[74] Grimaud A, Diaz-Morales O, Han B, et al. Activating lattice oxygen redox reactions in metal oxides to catalyse oxygen evolution. Nature chemistry, 2017, 9(5): 457. https://doi.org/10.1038/nchem.2695

[75] Liu X, Jia H, Sun Z, et al. Nanostructured copper oxide electrodeposited from copper (II) complexes as an active catalyst for electrocatalytic oxygen evolution reaction. Electrochemistry Communications, 2014, 46: 1-4. https://doi.org/10.1016/j.elecom.2014.05.029

[76] Xiao $\mathrm{C}, \mathrm{Li} \mathrm{Y}, \mathrm{Lu} \mathrm{X}$, et al. Bifunctional porous $\mathrm{NiFe} / \mathrm{NiCO}_{2} \mathrm{O}_{4} / \mathrm{Ni}$ foam electrodes with triple hierarchy and double synergies for efficient whole cell water splitting. Advanced Functional Materials, 2016, 26(20): 3515-3523. https://doi.org/10.1002/adfm.201505302

[77] McCrory CC, Jung S, Peters JC, et al. Benchmarking heterogeneous electrocatalysts for the oxygen evolution reaction. Journal of the American Chemical Society, 2013.
135(45): 16977-16987. https://doi.org/10.1021/ja407115p

[78] Li G, Anderson L, Chen Y, et al. New insights into evaluating catalyst activity and stability for oxygen evolution reactions in alkaline media. Sustainable Energy \& Fuels, 2018, 2(1): 237-251. https://doi.org/10.1039/C7SE00337D

[79] Qiu Y, Xin L and Li W. Electrocatalytic oxygen evolution over supported small amorphous $\mathrm{Ni}-\mathrm{Fe}$ nanoparticles in alkaline electrolyte. Langmuir, 2014, 30(26): 7893-7901. https://doi.org/10.1021/la501246e

[80] Dresp S, Luo F, Schmack R, et al. An efficient bifunctional two-component catalyst for oxygen reduction and oxygen evolution in reversible fuel cells, electrolyzers and rechargeable air electrodes. Energy \& Environmental Science, 2016, 9(6): 2020-2024. https://doi.org/10.1039/C6EE01046F

[81] Swesi AT, Masud J and Nath M. Nickel selenide as a highefficiency catalyst for oxygen evolution reaction. Energy \& Environmental Science, 2016, 9(5): 1771-1782. https://doi.org/10.1039/C5EE02463C

[82] $\mathrm{Hu} \mathrm{W}$, Wang Y, Hu X, et al. Three-dimensional ordered macroporous $\mathrm{IrO}_{2}$ as electrocatalyst for oxygen evolution reaction in acidic medium. Journal of Materials Chemistry, 2012, 22(13): 6010-6016. https://doi.org/10.1039/c2jm16506f

[83] Lee Y, Suntivich J, May KJ, et al. Synthesis and activities of rutile $\mathrm{IrO}_{2}$ and $\mathrm{RuO}_{2}$ nanoparticles for oxygen evolution in acid and alkaline solutions. The journal of physical chemistry letters, 2012, 3(3): 399-404. https://doi.org/10.1021/jz2016507

[84] Morales-Guio CG, Liardet L and Hu X. Oxidatively electrodeposited thin-film transition metal (oxy) hydroxides as oxygen evolution catalysts. Journal of the American Chemical Society, 2016, 138(28): 8946-8957. https://doi.org/10.1021/jacs.6b05196

[85] Batchellor AS and Boettcher SW. Pulse-electrodeposited $\mathrm{Ni}-\mathrm{Fe}$ (oxy) hydroxide oxygen evolution electrocatalysts with high geometric and intrinsic activities at large mass loadings. ACS Catalysis, 2015, 5(11): 6680-6689. https://doi.org/10.1021/acscatal.5b01551

[86] Schmidt T, Gasteiger H, Stäb G, et al. Characterization of highsurfacearea electrocatalysts using a rotating disk electrode configuration. Journal of The Electrochemical Society, 1998, 145(7): 2354-2358. https://doi.org/10.1149/1.1838642

[87] Paulus U, Schmidt T, Gasteiger H, et al. Oxygen reduction on a high-surface area Pt/Vulcan carbon catalyst: a thin-film rotating ring-disk electrode study. Journal of Electroanalytical Chemistry, 2001, 495(2): 134-145. https://doi.org/10.1016/S0022-0728(00)00407-1

[88] Armaroli N and Balzani V. The future of energy supply: challenges and opportunities. Angewandte Chemie International Edition, 2007, 46(1-2): 52-66. https://doi.org/10.1002/anie.200602373

[89] Perlo P. Catalysis for Sustainable Energy Production. 2009, 89-105.

[90] Knözinger H, Infrared spectroscopy for the characterization of surface acidity and basicity. Handbook of Heterogeneous Catalysis: Online, 2008: 1135-1163. https://doi.org/10.1002/9783527610044.hetcat0059 
[91] Lobyntseva E, Kallio T, Alexeyeva N, et al. Electrochemical synthesis of hydrogen peroxide: Rotating disk electrode and fuel cell studies. Electrochimica Acta, 2007, 52(25): 72627269. https://doi.org/10.1016/j.electacta.2007.05.076

[92] Yamanaka I, Hashimoto T, Ichihashi R, et al. Direct synthesis of $\mathrm{H}_{2} \mathrm{O}_{2}$ acid solutions on carbon cathode prepared from activated carbon and vapor-growing-carbon-fiber by a $\mathrm{H}_{2} / \mathrm{O}_{2}$ fuel cell. Electrochimica Acta, 2008, 53(14): 48244832.

https://doi.org/10.1016/j.electacta.2008.02.009

[93] Schulenburg H, Stankov S, Schünemann V, et al. Catalysts for the oxygen reduction from heat-treated iron (III) tetramethoxyphenylporphyrin chloride: structure and stability of active sites. The Journal of Physical Chemistry B, 2003, 107(34): 9034-9041. https://doi.org/10.1021/jp030349j

[94] Bezerra CW, Zhang L, Lee K, et al. A review of $\mathrm{Fe}-\mathrm{N} / \mathrm{C}$ and $\mathrm{Co}-\mathrm{N} / \mathrm{C}$ catalysts for the oxygen reduction reaction. Electrochimica Acta, 2008, 53(15): 4937-4951. https://doi.org/10.1016/j.electacta.2008.02.012

[95] Siahrostami S, Verdaguer-Casadevall A, Karamad M, et al. Enabling direct $\mathrm{H}_{2} \mathrm{O}_{2}$ production through rational electrocatalyst design. Nature materials, 2013, 12(12): 1137. https://doi.org/10.1038/nmat3795

[96] Sheng W, Gasteiger HA and Shao-Horn Y. Hydrogen oxidation and evolution reaction kinetics on platinum: acid vs alkaline electrolytes. Journal of The Electrochemical Society, 2010, 157(11): 1529-1536. https://doi.org/10.1149/1.3483106

[97] Ayers KE, Dalton LT and Anderson EB. Efficient generation of high energy density fuel from water. ECS Transactions, 2012, 41(33): 27-38. https://doi.org/10.1149/1.3702410

[98] Viswanathan V, Hansen HA, Rossmeisl J, et al. Unifying the $2 \mathrm{e}$-and $4 \mathrm{e}$-reduction of oxygen on metal surfaces. The journal of physical chemistry letters, 2012, 3(20): 2948-2951. https://doi.org/10.1021/jz301476w

[99] Greeley J, Stephens I, Bondarenko A, et al. Alloys of platinum and early transition metals as oxygen reduction electrocatalysts. Nature chemistry, 2009, 1(7): 552. https://doi.org/10.1038/nchem.367

[100] Nrskov JK, Bligaard T, Rossmeisl J, et al. Towards the computational design of solid catalysts. Nature chemistry, 2009, 1(1): 37 . https://doi.org/10.1038/nchem.121

[101] Koper MT. Thermodynamic theory of multi-electron transfer reactions: Implications for electrocatalysis. Journal of Electroanalytical Chemistry, 2011, 660(2): 254-260. https://doi.org/10.1016/j.jelechem.2010.10.004

[102] Stephens IE, Bondarenko AS, Grnbjerg U, et al. Understanding the electrocatalysis of oxygen reduction on platinum and its alloys. Energy \& Environmental Science, 2012, 5(5): 6744-6762. https://doi.org/10.1039/c2ee03590a

[103] Verdaguer-Casadevall A, Deiana D, Karamad M, et al. Trends in the electrochemical synthesis of $\mathrm{H}_{2} \mathrm{O}_{2}$ : enhancing activity and selectivity by electrocatalytic site engineering. Nano letters, 2014, 14(3): 1603-1608. https://doi.org/10.1021/nl500037x
[104] Choi CH, Kwon HC, Yook S, et al. Hydrogen peroxide synthesis via enhanced two-electron oxygen reduction pathway on carbon-coated Pt surface. The Journal of Physical Chemistry C, 2014, 118(51): 30063-30070. https://doi.org/10.1021/jp5113894

[105] Park J, Nabae Y, Hayakawa T, et al. Highly selective two-electron oxygen reduction catalyzed by mesoporous nitrogen-doped carbon. ACS Catalysis, 2014, 4(10): 37493754. https://doi.org/10.1021/cs5008206

[106] Choi CH, Kim M, Kwon HC, et al. Tuning selectivity of electrochemical reactions by atomically dispersed platinum catalyst. Nature communications, 2016, 7: 10922. https://doi.org/10.1038/ncomms 10922

[107] Mase K, Yoneda M, Yamada Y, et al. Seawater usable for production and consumption of hydrogen peroxide as a solar fuel. Nature communications, 2016, 7: 11470 . https://doi.org/10.1038/ncomms11470

[108] Izgorodin A, Izgorodina E and MacFarlane DR. Low overpotential water oxidation to hydrogen peroxide on a $\mathrm{MnO}$ x catalyst. Energy \& Environmental Science, 2012, 5(11): 9496-9501. https://doi.org/10.1039/c2ee21832a

[109] McDonnell-Worth C and MacFarlane DR. Ion effects in water oxidation to hydrogen peroxide. RSC Advances, 2014, 4(58): 30551-30557. https://doi.org/10.1039/C4RA05296J

[110] Viswanathan V, Hansen HA and Nrskov JK. Selective electrochemical generation of hydrogen peroxide from water oxidation. The journal of physical chemistry letters, 2015, 6(21): 4224-4228. https://doi.org/10.1021/acs.jpclett.5b02178

[111] Fuku K and Sayama K. Efficient oxidative hydrogen peroxide production and accumulation in photoelectrochemical water splitting using a tungsten trioxide/bismuth vanadate photoanode. Chemical Communications, 2016, 52(31): 5406-5409. https://doi.org/10.1039/C6CC01605G

[112] Reier T, Oezaslan M and Strasser P. Electrocatalytic oxygen evolution reaction (OER) on $\mathrm{Ru}$, Ir, and Pt catalysts: a comparative study of nanoparticles and bulk materials. Acs Catalysis, 2012, 2(8): 1765-1772. https://doi.org/10.1021/cs3003098

[113] Fabbri E, Habereder A, Waltar K, et al. Developments and perspectives of oxide-based catalysts for the oxygen evolution reaction. Catalysis Science \& Technology, 2014, 4(11): 3800-3821. https://doi.org/10.1039/C4CY00669K

[114] Burke MS, Enman LJ, Batchellor AS, et al. Oxygen evolution reaction electrocatalysis on transition metal oxides and (oxy) hydroxides: activity trends and design principles. Chemistry of Materials, 2015, 27(22): 7549-7558. https://doi.org/10.1021/acs.chemmater.5b03148

[115] Cheng Y and Jiang SP. Advances in electrocatalysts for oxygen evolution reaction of water electrolysis-from metal oxides to carbon nanotubes. Progress in natural science: materials international, 2015, 25(6): 545-553. https://doi.org/10.1016/j.pnsc.2015.11.008 
[116] Diaz-Morales O, Ledezma-Yanez I, Koper MT, et al. Guidelines for the rational design of Ni-based double hydroxide electrocatalysts for the oxygen evolution reaction. ACS Catalysis, 2015, 5(9): 5380-5387. https://doi.org/10.1021/acscatal.5b01638

[117] Gong M and Dai H. A mini review of NiFe-based materials as highly active oxygen evolution reaction electrocatalysts. Nano Research, 2015, 8(1): 23-39. https://doi.org/10.1007/s12274-014-0591-z

[118] Diaz-Morales O, Raaijman S, Kortlever R, et al. Iridiumbased double perovskites for efficient water oxidation in acid media. Nature communications, 2016, 7: 12363. https://doi.org/10.1038/ncomms12363

[119] Han B, Risch M, Lee YL, et al. Activity and stability trends of perovskite oxides for oxygen evolution catalysis at neutral pH. Physical Chemistry Chemical Physics, 2015, 17(35): 22576-22580. https://doi.org/10.1039/C5CP04248H

[120] Dionigi F and Strasser P. NiFe-Based (Oxy) hydroxide Catalysts for Oxygen Evolution Reaction in NonAcidic Electrolytes. Advanced Energy Materials, 2016, 6(23): 1600621. https://doi.org/10.1002/aenm.201600621

[121] Reier T, Nong HN, Teschner D, et al. Electrocatalytic oxygen evolution reaction in acidic environments-reaction mechanisms and catalysts. Advanced Energy Materials, 2017, 7(1): 1601275. https://doi.org/10.1002/aenm.201601275

[122] Spoeri C, Kwan JTH, Bonakdarpour A, et al. The stability challenges of oxygen evolving catalysts: Towards a common fundamental understanding and mitigation of catalyst degradation. Angewandte Chemie International Edition, 2017, 56(22): 5994-6021. https://doi.org/10.1002/anie.201608601

[123] Burke MS, Zou S, Enman LJ, et al. Revised oxygen evolution reaction activity trends for first-row transition-metal (oxy) hydroxides in alkaline media. The journal of physical chemistry letters, 2015, 6(18): 3737-3742. https://doi.org/10.1021/acs.jpclett.5b01650

[124] Hong WT, Welsch RE and Shao-Horn Y. Descriptors of oxygen-evolution activity for oxides: a statistical evaluation. The Journal of Physical Chemistry C, 2015, 120(1): 78-86. https://doi.org/10.1021/acs.jpcc.5b10071

[125] Zou S, Burke MS, Kast MG, et al. Fe(oxy) hydroxide oxygen evolution reaction electrocatalysis: Intrinsic activity and the roles of electrical conductivity, substrate, and dissolution. Chemistry of Materials, 2015, 27(23): 8011-8020. https://doi.org/10.1021/acs.chemmater.5b03404

[126] Fuku K, Miyase Y, Miseki Y, et al. Enhanced oxidative hydrogen peroxide production on conducting glass anodes modified with metal oxides. ChemistrySelect, 2016, 1(18): 5721-5726. https://doi.org/10.1002/slct.201601469

[127] Fuku K, Miyase Y, Miseki Y, et al. Photoelectrochemical hydrogen peroxide production from water on a $\mathrm{WO}_{3} / \mathrm{BiVO}_{4}$ photoanode and from $\mathrm{O}_{2}$ on an $\mathrm{Au}$ cathode without external bias. Chemistry-An Asian Journal, 2017, 12(10): 11111119.

https://doi.org/10.1002/asia.201700292
[128] Cai R, Kubota Y and Fujishima A. Effect of copper ions on the formation of hydrogen peroxide from photocatalytic titanium dioxide particles. Journal of Catalysis, 2003, 219(1): 214-218. https://doi.org/10.1016/S0021-9517(03)00197-0

[129] Goto H, Hanada Y, Ohno T, et al. Quantitative analysis of superoxide ion and hydrogen peroxide produced from molecular oxygen on photoirradiated $\mathrm{TiO}_{2}$ particles. Journal of Catalysis, 2004, 225(1): 223-229. https://doi.org/10.1016/j.jcat.2004.04.001

[130] Hirakawa T, Yawata K and Nosaka Y. Photocatalytic reactivity for $\mathrm{O}^{2}$ and $\mathrm{OH}$ radical formation in anatase and rutile $\mathrm{TiO}_{2}$ suspension as the effect of $\mathrm{H}_{2} \mathrm{O}_{2}$ addition. Applied Catalysis A: General, 2007, 325(1): 105-111. https://doi.org/10.1016/j.apcata.2007.03.015

[131] Zhang J and Nosaka Y. Quantitative detection of OH radicals for investigating the reaction mechanism of various visible-light $\mathrm{TiO}_{2}$ photocatalysts in aqueous suspension. The Journal of Physical Chemistry C, 2013, 117(3): 13831391. https://doi.org/10.1021/jp3105166

[132] Sánchez-Quiles D and Tovar-Sánchez A. Sunscreens as a source of hydrogen peroxide production in coastal waters. Environmental science \& technology, 2014, 48(16): 90379042. https://doi.org/10.1021/es5020696

[133] Shi X, Siahrostami S, Li GL, et al. Understanding activity trends in electrochemical water oxidation to form hydrogen peroxide. Nature communications, 2017, 8(1): 701. https://doi.org/10.1038/s41467-017-00585-6

[134] Stamenkovic VR, Mun BS, Arenz M, et al. Trends in electrocatalysis on extended and nanoscale Pt-bimetallic alloy surfaces. Nature materials, 2007, 6(3): 241. https://doi.org/10.1038/nmat1840

[135] Stephens IE, Bondarenko AS, Perez-Alonso FJ, et al. Tuning the activity of Pt (111) for oxygen electroreduction by subsurface alloying. Journal of the American Chemical Society, 2011, 133(14): 5485-5491. https://doi.org/10.1021/ja111690g

[136] Suntivich J, May KJ, Gasteiger HA, et al. A perovskite oxide optimized for oxygen evolution catalysis from molecular orbital principles. Science, 2011, 334(6061): 1383-1385. https://doi.org/10.1126/science.1212858

[137] Bandarenka AS, Varela AS, Karamad M, et al. Design of an Active Site towards Optimal Electrocatalysis: Overlayers, Surface Alloys and Near-Surface Alloys of $\mathrm{Cu} / \mathrm{Pt}$ (111). Angewandte Chemie International Edition, 2012, 51(47): $11845-11848$. https://doi.org/10.1002/anie.201205314

[138] Subbaraman R, Tripkovic D, Chang KC, et al. Trends in activity for the water electrolyser reactions on $3 \mathrm{~d} M(\mathrm{Ni}$, $\mathrm{Co}, \mathrm{Fe}, \mathrm{Mn}$ ) hydr (oxy) oxide catalysts. Nature materials, 2012, 11(6): 550. https://doi.org/10.1038/nmat3313

[139] Hinnemann B, Moses PG, Bonde J, et al. Biomimetic hydrogen evolution: $\mathrm{MoS}_{2}$ nanoparticles as catalyst for hydrogen evolution. Journal of the American Chemical Society, 2005, 127(15): 5308-5309. https://doi.org/10.1021/ja0504690 
[140] Stamenkovic VR, Fowler B, Mun BS, et al. Improved oxygen reduction activity on $\mathrm{Pt} 3 \mathrm{Ni}$ (111) via increased surface site availability. science, 2007, 315(5811): 493-497. https://doi.org/10.1126/science.1135941

[141] Li GL. First-principles investigation of the surface properties of fergusonite-type monoclinic $\mathrm{BiVO}_{4}$ photocatalyst. RSC Advances, 2017, 7(15): 9130-9140. https://doi.org/10.1039/C6RA28006D

[142] Man IC, Su HY, Calle-Vallejo F, et al. Universality in oxygen evolution electrocatalysis on oxide surfaces. ChemCatChem, 2011, 3(7): 1159-1165. https://doi.org/10.1002/cctc.201000397

[143] Siahrostami S, Björketun ME, Strasser P, et al. Tandem cathode for proton exchange membrane fuel cells. Physical Chemistry Chemical Physics, 2013, 15(23): 9326-9334. https://doi.org/10.1039/c3cp51479j

[144] Montoya JH, Garcia-Mota M, Nrskov JK, et al. Theoretical evaluation of the surface electrochemistry of perovskites with promising photon absorption properties for solar water splitting. Physical Chemistry Chemical Physics, 2015, 17(4): 2634-2640. https://doi.org/10.1039/C4CP05259E

[145] Nrskov JK, Rossmeisl J, Logadottir A, et al. Origin of the overpotential for oxygen reduction at a fuel-cell cathode. The Journal of Physical Chemistry B, 2004, 108(46): 17886-17892. https://doi.org/10.1021/jp047349j

[146] Siahrostami S, Li GL, Viswanathan V, et al. One or two electron water oxidation, hydroxyl radical, or $\mathrm{H}_{2} \mathrm{O}_{2}$ evolution. The Journal of Physical Chemistry Letters, 2017, 8(6): 1157-1160. https://doi.org/10.1021/acs.jpclett.6b02924

[147] Wu HL, Yau S and Zei MS Crystalline alloys produced by mercury electrodeposition on Pt $\left(\begin{array}{lll}1 & 1 & 1\end{array}\right)$ electrode at room temperature. Electrochimica Acta, 2008, 53(20): 59615967.

https://doi.org/10.1016/j.electacta.2008.03.063

[148] Erikson H, Jürmann G, Sarapuu A, et al. Electroreduction of oxygen on carbon-supported gold catalysts. Electrochimica Acta, 2009, 54(28): 7483-7489. https://doi.org/10.1016/j.electacta.2009.08.001

[149] Jirkovskv JS, Halasa M and Schiffrin DJ. Kinetics of electrocatalytic reduction of oxygen and hydrogen peroxide on dispersed gold nanoparticles. Physical Chemistry Chemical Physics, 2010, 12(28): 8042-8053. https://doi.org/10.1039/c002416c

[150] Gasteiger HA and Markovic NM. Just a dream-or future reality? Science, 2009, 324(5923): 48-49. https://doi.org/10.1126/science.1172083

[151] Vesborg PC and Jaramillo TF. Addressing the terawatt challenge: scalability in the supply of chemical elements for renewable energy. Rsc Advances, 2012, 2(21): 7933-7947. https://doi.org/10.1039/c2ra20839c

[152] Mayrhofer KJ, Juhart V, Hartl K, et al. Adsorbate-Induced Surface Segregation for Core-Shell Nanocatalysts. Angewandte Chemie International Edition, 2009, 48(19): 35293531.

https://doi.org/10.1002/anie.200806209
[153] Sasaki K, Naohara H, Cai Y, et al. Core-protected platinum monolayer shell high-stability electrocatalysts for fuel-cell cathodes. Angewandte Chemie International Edition, 2010, 49(46): 8602-8607. https://doi.org/10.1002/anie.201004287

[154] Cui C, Gan L, Heggen M, et al. Compositional segregation in shaped Pt alloy nanoparticles and their structural behaviour during electrocatalysis. Nature materials, 2013, 12(8): 765 https://doi.org/10.1038/nmat3668

[155] Guo S, Li D, Zhu H, et al. FePt and CoPt nanowires as efficient catalysts for the oxygen reduction reaction. Angewandte Chemie, 2013, 125(12): 3549-3552. https://doi.org/10.1002/ange.201209871

[156] Wang D, Xin HL, Hovden R, et al. Structurally ordered intermetallic platinum-cobalt core-shell nanoparticles with enhanced activity and stability as oxygen reduction electrocatalysts. Nature materials, 2013, 12(1): 81. https://doi.org/10.1038/nmat3458

[157] Tomita A, Nakajima J and Hibino T. Direct oxidation of methane to methanol at low temperature and pressure in an electrochemical fuel cell. Angewandte Chemie, 2008, 120(8): $1484-1486$ https://doi.org/10.1002/ange.200703928

[158] Kuhl KP, Cave ER, Abram DN, et al. New insights into the electrochemical reduction of carbon dioxide on metallic copper surfaces. Energy \& Environmental Science, 2012, 5(5): 7050-7059. https://doi.org/10.1039/c2ee21234j

[159] Li CW and Kanan MW. $\mathrm{CO}_{2}$ reduction at low overpotential on $\mathrm{Cu}$ electrodes resulting from the reduction of thick $\mathrm{Cu} 2 \mathrm{O}$ films. Journal of the American Chemical Society, 2012, 134(17): 7231-7234. https://doi.org/10.1021/ja3010978

[160] Rivero PJ, Ibaez E, Goicoechea J, et al. A self-referenced optical colorimetric sensor based on silver and gold nanoparticles for quantitative determination of hydrogen peroxide. Sensors and Actuators B: Chemical, 2017, 251: 624-631. https://doi.org/10.1016/j.snb.2017.05.110

[161] Gomes A, Fernandes E and Lima JL. Fluorescence probes used for detection of reactive oxygen species. Journal of biochemical and biophysical methods, 2005, 65(2-3): 4580. https://doi.org/10.1016/j.jbbm.2005.10.003

[162] Hanaoka S, Lin JM and Yamada M. Chemiluminescent flow sensor for $\mathrm{H}_{2} \mathrm{O}_{2}$ based on the decomposition of $\mathrm{H}_{2} \mathrm{O}_{2}$ catalyzed by cobalt (II)-ethanolamine complex immobilized on resin. Analytica Chimica Acta, 2001, 426(1): 57-64 https://doi.org/10.1016/S0003-2670(00)01181-8

[163] Nogueira RFP, Oliveira MC and Paterlini WC. Simple and fast spectrophotometric determination of $\mathrm{H}_{2} \mathrm{O}_{2}$ in photoFenton reactions using metavanadate. Talanta, 2005, 66(1): 86-91. https://doi.org/10.1016/j.talanta.2004.10.001

[164] Ma L, Yuan R, Chai Y, et al. Amperometric hydrogen peroxide biosensor based on the immobilization of HRP on DNA-silver nanohybrids and PDDA-protected gold nanoparticles. Journal of Molecular Catalysis B: Enzymatic, 2009, 56(4): 215-220. https://doi.org/10.1016/j.molcatb.2008.05.007 
[165] Khan AY and Bandyopadhyaya R. Silver nanoparticle impregnated mesoporous silica as a non-enzymatic amperometric sensor for an aqueous solution of hydrogen peroxide. Journal of Electroanalytical Chemistry, 2014, 727: 184-190. https://doi.org/10.1016/j.jelechem.2014.05.027

[166] Zhang L, Zhai Y, Gao N, et al. Sensing $\mathrm{H}_{2} \mathrm{O}_{2}$ with layer-bylayer assembled $\mathrm{Fe}_{3} \mathrm{O}_{4}$-PDDA nanocomposite film. Electrochemistry Communications, 2008, 10(10): 1524-1526. https://doi.org/10.1016/j.elecom.2008.05.022

[167] Dhara K, Ramachandran T, Nair BG, et al. Au nanoparticles decorated reduced graphene oxide for the fabrication of disposable nonenzymatic hydrogen peroxide sensor. Journal of Electroanalytical Chemistry, 2016, 764: 64-70. https://doi.org/10.1016/j.jelechem.2016.01.011

[168] Becerril HA, Mao J, Liu Z, et al. Evaluation of solutionprocessed reduced graphene oxide films as transparent conductors. ACS nano, 2008, 2(3): 463-470. https://doi.org/10.1021/nn700375n

[169] Shin HJ, Kim KK, Benayad A, et al. Efficient reduction of graphite oxide by sodium borohydride and its effect on electrical conductance. Advanced Functional Materials, 2009, 19(12): 1987-1992. https://doi.org/10.1002/adfm.200900167

[170] Xiong D, Li X, Shan H, et al. Oxygen-containing functional groups enhancing electrochemical performance of porous reduced graphene oxide cathode in lithium ion batteries. Electrochimica Acta, 2015, 174: 762-769. https://doi.org/10.1016/j.electacta.2015.06.041

[171] Amanulla B, Palanisamy S, Chen SM, et al. A nonenzymatic amperometric hydrogen peroxide sensor based on iron nanoparticles decorated reduced graphene oxide nanocomposite. Journal of colloid and interface science, 2017, 487: 370-377. https://doi.org/10.1016/j.jcis.2016.10.050

[172] Jiang Y, Zheng B, Du J, et al. Electrophoresis deposition of $\mathrm{Ag}$ nanoparticles on $\mathrm{TiO}_{2}$ nanotube arrays electrode for hydrogen peroxide sensing. Talanta, 2013, 112: 129-135. https://doi.org/10.1016/j.talanta.2013.03.015

[173] Li X, Liu X, Wang W, et al. High loading Pt nanoparticles on functionalization of carbon nanotubes for fabricating nonenzyme hydrogen peroxide sensor. Biosensors and Bioelectronics, 2014, 59: 221-226. https://doi.org/10.1016/j.bios.2014.03.046

[174] Ensafi AA, Zandi-Atashbar N, Rezaei B, et al. Silver nanoparticles decorated carboxylate functionalized $\mathrm{SiO}_{2}$, New nanocomposites for non-enzymatic detection of glucose and hydrogen peroxide. Electrochimica Acta, 2016, 214: 208-216. https://doi.org/10.1016/j.electacta.2016.08.047

[175] Mei H, Wu W, Yu B, et al. Nonenzymatic electrochemical sensor based on Fe@ Pt core-shell nanoparticles for hydrogen peroxide, glucose and formaldehyde. Sensors and Actuators B: Chemical, 2016, 223: 68-75. https://doi.org/10.1016/j.snb.2015.09.044

[176] Li X and Du X. Molybdenum disulfide nanosheets supported $\mathrm{Au}-\mathrm{Pd}$ bimetallic nanoparticles for non-enzymatic electrochemical sensing of hydrogen peroxide and glucose. Sensors and Actuators B: Chemical, 2017, 239: 536-543. https://doi.org/10.1016/j.snb.2016.08.048
[177] Li D, Meng L, Xiao P, et al. Enhanced non-enzymatic electrochemical sensing of hydrogen peroxide based on $\mathrm{Cu}_{2} \mathrm{O}$ nanocubes/Ag-Au alloy nanoparticles by incorporation of RGO nanosheets. Journal of Electroanalytical Chemistry, 2017, 791: 23-28. https://doi.org/10.1016/j.jelechem.2017.03.010

[178] Zhang C, Zhang Y, Du X, et al. Facile fabrication of Pt-Ag bimetallic nanoparticles decorated reduced graphene oxide for highly sensitive non-enzymatic hydrogen peroxide sensing. Talanta, 2016, 159: 280-286. https://doi.org/10.1016/j.talanta.2016.06.047

[179] Liu P, Li J, Liu X, et al. One-pot synthesis of highly dispersed PtAu nanoparticles-CTAB-graphene nanocomposites for nonenzyme hydrogen peroxide sensor. Journal of Electroanalytical Chemistry, 2015, 751: 1-6. https://doi.org/10.1016/j.jelechem.2015.05.027

[180] Guler M, Turkoglu V, Bulut A, et al. Electrochemical sensing of hydrogen peroxide using Pd@ Ag bimetallic nanoparticles decorated functionalized reduced graphene oxide. Electrochimica Acta, 2018. 263: 118-126. https://doi.org/10.1016/j.electacta.2018.01.048

[181] Barros WR, Wei Q, Zhang G, et al. Oxygen reduction to hydrogen peroxide on $\mathrm{Fe}_{3} \mathrm{O}_{4}$ nanoparticles supported on Printex carbon and Graphene. Electrochimica Acta, 2015, 162: 263-270. https://doi.org/10.1016/j.electacta.2015.02.175

[182] Li L, Li L, Wang C, et al. Synthesis of nitrogen-doped and amino acid-functionalized graphene quantum dots from glycine, and their application to the fluorometric determination of ferric ion. Microchimica Acta, 2015, 182(3-4): 763770 .

https://doi.org/10.1007/s00604-014-1383-6

[183] Pizzutilo E, Kasian O, Choi C H, et al. Electrocatalytic synthesis of hydrogen peroxide on Au-Pd nanoparticles: From fundamentals to continuous production. Chemical Physics Letters, 2017, 683: 436-442. https://doi.org/10.1016/j.cplett.2017.01.071

[184] Lu Y, Jiang Y, Gao X, et al. Charge state-dependent catalytic activity of [Au $25\left(\mathrm{SC} 12 \mathrm{H}_{2} 5\right) 18$ ] nanoclusters for the two-electron reduction of dioxygen to hydrogen peroxide. Chemical Communications, 2014, 50(62): 8464-8467. https://doi.org/10.1039/C4CC01841A

[185] Lu Z, Chen G, Siahrostami S, et al. High-efficiency oxygen reduction to hydrogen peroxide catalysed by oxidized carbon materials. Nature Catalysis, 2018, 1(2): 156. https://doi.org/10.1038/s41929-017-0017-x

[186] Assumpao M, Moraes A, De Souza R, et al. Low content cerium oxide nanoparticles on carbon for hydrogen peroxide electrosynthesis. Applied Catalysis A: General, 2012, 411: $1-6$. https://doi.org/10.1016/j.apcata.2011.09.030

[187] Chen Z, Chen S, Siahrostami S, et al. Development of a reactor with carbon catalysts for modular-scale, low-cost electrochemical generation of $\mathrm{H}_{2} \mathrm{O}_{2}$. Reaction Chemistry \& Engineering, 2017, 2(2): 239-245. https://doi.org/10.1039/C6RE00195E

[188] Assumpo M, De Souza R, Rascio D, et al. A comparative study of the electrogeneration of hydrogen peroxide using Vulcan and Printex carbon supports. Carbon, 2011, 49(8): 2842-2851. https://doi.org/10.1016/j.carbon.2011.03.014 
[189] Barros WR, Reis RM, Rocha RS, et al. Electrogeneration of hydrogen peroxide in acidic medium using gas diffusion electrodes modified with cobalt (II) phthalocyanine. Electrochimica Acta, 2013, 104: 12-18. https://doi.org/10.1016/j.electacta.2013.04.079

[190] Sun Y, Sinev I, Ju W, et al. Efficient Electrochemical Hydrogen Peroxide Production from Molecular Oxygen on Nitrogen-Doped Mesoporous Carbon Catalysts. ACS Catalysis, 2018, 8(4): 2844-2856. https://doi.org/10.1021/acscatal.7b03464

[191] Kim HW, Ross MB, Kornienko N, et al. Efficient hydrogen peroxide generation using reduced graphene oxide-based oxygen reduction electrocatalysts. Nature Catalysis, 2018, 1(4): 282. https://doi.org/10.1038/s41929-018-0044-2

[192] Prathap MA, Thakur B, Sawant SN, et al. Synthesis of mesostructured polyaniline using mixed surfactants, anionic sodium dodecylsulfate and non-ionic polymers and their applications in $\mathrm{H}_{2} \mathrm{O}_{2}$ and glucose sensing. Colloids and Surfaces B: Biointerfaces, 2012, 89: 108-116. https://doi.org/10.1016/j.colsurfb.2011.09.002

[193] Wang Y, Tang M, Lin X, et al. Sensor for hydrogen peroxide using a hemoglobin-modified glassy carbon electrode prepared by enhanced loading of silver nanoparticle onto carbon nanospheres via spontaneous polymerization of dopamine. Microchimica Acta, 2012, 176(3-4): 405-410. https://doi.org/10.1007/s00604-011-0736-7

[194] Anjalidevi C, Dharuman V and Narayanan JS. Non enzymatic hydrogen peroxide detection at ruthenium oxide-gold nano particle-Nafion modified electrode. Sensors and Actuators B: Chemical, 2013, 182: 256-263. https://doi.org/10.1016/j.snb.2013.03.006

[195] Ricci F and Palleschi G. Sensor and biosensor preparation, optimisation and applications of Prussian Blue modified electrodes. Biosensors and Bioelectronics, 2005, 21(3): 389-407. https://doi.org/10.1016/j.bios.2004.12.001

[196] Karyakin AA, Kuritsyna EA, Karyakina EE, et al. Diffusion controlled analytical performances of hydrogen peroxide sensors: Towards the sensor with the largest dynamic range. Electrochimica Acta, 2009, 54(22): 5048-5052. https://doi.org/10.1016/j.electacta.2008.11.049

[197] Arduini F, Ricci F, Tuta CS, et al. Detection of carbamic and organophosphorous pesticides in water samples using a cholinesterase biosensor based on Prussian Blue-modified screen-printed electrode. Analytica Chimica Acta, 2006,
580(2): $155-162$.

https://doi.org/10.1016/j.aca.2006.07.052

[198] Haghighi B, Hamidi H and Gorton L. Electrochemical behavior and application of Prussian blue nanoparticle modified graphite electrode. Sensors and Actuators B: Chemical, 2010, 147(1): 270-276. https://doi.org/10.1016/j.snb.2010.03.020

[199] Cao L, Liu Y, Zhang B, et al. In situ controllable growth of Prussian blue nanocubes on reduced graphene oxide: facile synthesis and their application as enhanced nanoelectrocatalyst for $\mathrm{H}_{2} \mathrm{O}_{2}$ reduction. ACS applied materials \& interfaces, 2010, 2(8): 2339-2346. https://doi.org/10.1021/am100372m

[200] Li N, He B, Xu S, et al. In site formation and growth of Prussian blue nanoparticles anchored to multiwalled carbon nanotubes with poly (4-vinylpyridine) linker by layerby-layer assembly. Materials Chemistry and Physics, 2012, 133(2-3): 726-734. https://doi.org/10.1016/j.matchemphys.2012.01.074

[201] Huang L, Huang Y, Liang J, et al. Graphene-based conducting inks for direct inkjet printing of flexible conductive patterns and their applications in electric circuits and chemical sensors. Nano Research, 2011, 4(7): 675-684. https://doi.org/10.1007/s12274-011-0123-z

[202] Minemawari H, Yamada T, Matsui H, et al. Inkjet printing of single-crystal films. Nature, 2011, 475(7356): 364. https://doi.org/10.1038/nature10313

[203] Hibbard T, Crowley K and Killard AJ. Direct measurement of ammonia in simulated human breath using an inkjetprinted polyaniline nanoparticle sensor. Analytica chimica acta, 2013, 779: 56-63. https://doi.org/10.1016/j.aca.2013.03.051

[204] Gonzalez-Macia L, Morrin A, Smyth MR, et al. Advanced printing and deposition methodologies for the fabrication of biosensors and biodevices. Analyst, 2010, 135(5): 845-867. https://doi.org/10.1039/b916888e

[205] Cinti S, Arduini F, Moscone D, et al. Development of a hydrogen peroxide sensor based on screen-printed electrodes modified with inkjet-printed Prussian blue nanoparticles. Sensors, 2014, 14(8): 14222-14234. https://doi.org/10.3390/s140814222

[206] Hu JY, Lin YP and Liao YC. Inkjet printed Prussian Blue films for hydrogen peroxide detection. Analytical sciences, 2012, 28(2): 135-135. https://doi.org/10.2116/analsci.28.135 